\title{
LOWER BASHKIRIAN FUSULINOIDEANS FROM THE UPPER PART OF THE TAGNANA FORMATION (CARBONIFEROUS, NW ALGERIA)
}

\author{
Adriaan C. van GINKEL
}

National Museum of Natural History, Post Box 9517, 2300 RA Leiden, The Netherlands.

Ginkel, A.C. van. 2002. Lower Bashkirian fusulinoideans from the upper part of the Tagnana Formation (Carboniferous, NW Algeria). [Fusulinoideos del Bashkiriense Inferior de la parte alta de la Formación Tagnana (Carbonífero, NO Argelia).] Revista Española de Paleontología, 17(1), 37-72. ISSN 0213-6937.

\begin{abstract}
The upper member of the Tagnana Formation of the Djebel Béchar Group (informally the Tagnana- 3 or Tagnana III member) yielded fusulinoideans and other related foraminifera of the genera Pseudoendothyra (rare), Pseudostaffella (Semistaffella) (rare), Millerella, Pseudonovella, Plectostaffella, Eostaffella and Mediocris. The presence of Eostaffellina (rare) and Endostaffella is doubtful. The difference between Millerella and Eostaffella cannot be adequately defined by evolute versus involute coiling. Pseudonovella Kireeva, 1949 is redefined to include Seminovella Rauzer-Chernousova, 1951

The foraminifera are from two samples, one from close to the top and the other from near the base of the Tagnana III Member. Conodonts from the same samples, in comparison with the fusulinoidean foraminifera indicate similar or slightly younger ages; combined evidence from conodonts and foraminifera shows that the Tagnana-III Member at its upper boundary is Askynbashky or Akavassky (probably late Akavassky), while its lower boundary is Akavassky or Siuransky (probably late Siuransky) in age.
\end{abstract}

Keywords: Fusulinoideans, taxonomy, biostratigraphy, Carboniferous, Lower Bashkirian, Tagnana Formation, Algeria.

\section{RESUMEN}

El miembro superior de la Formación Tagnana (Grupo Djebel Béchar, NO de Argelia), denominado informalmente Miembro Tagnana-3 o Tagnana-III, ha proporcionado foraminíferos, especialmente fusulinoideos, pertenecientes a los géneros Pseudoendothyra (escaso), Pseudostaffella (Semistaffella) (escaso), Millerella, Pseudonovella, Plectostaffella, Eostaffella y Mediocris. La presencia de Eostaffellina (escaso) y de Endostaffella es dudosa. En este trabajo se discuten las diferencias entre los géneros Millerella y Eostaffella, cuya separación no puede establecerse de manera adecuada sobre la base del carácter evoluto o involuto del arrollamiento del caparazón. Además, se redefine el género Pseudonovella Kireeva, 1949, incluyendo en él a Seminovella RauzerChernousova, 1951.

Los foraminíferos hallados proceden de dos muestras, una de ellas cercana a la base y la otra próxima al techo del Miembro Tagnana-III. Los conodontos procedentes de las mismas muestras señalan edades similares o ligeramente más jóvenes que las proporcionadas por los fusulinoideos. Combinando datos de ambos grupos se obtiene que el techo del Miembro Tagnana-III es Askynbashky o Akavassky (probablemente Akavassky superior), mientras que la base de dicha unidad es Akavassky o Siuransky (probablemente Siuransky superior).

Palabras clave: Fusulinoideos, taxonomía, bioestratigrafía, Carbonífero, Bashkiriense Inferior, Formación Tagnana, Argelia. 

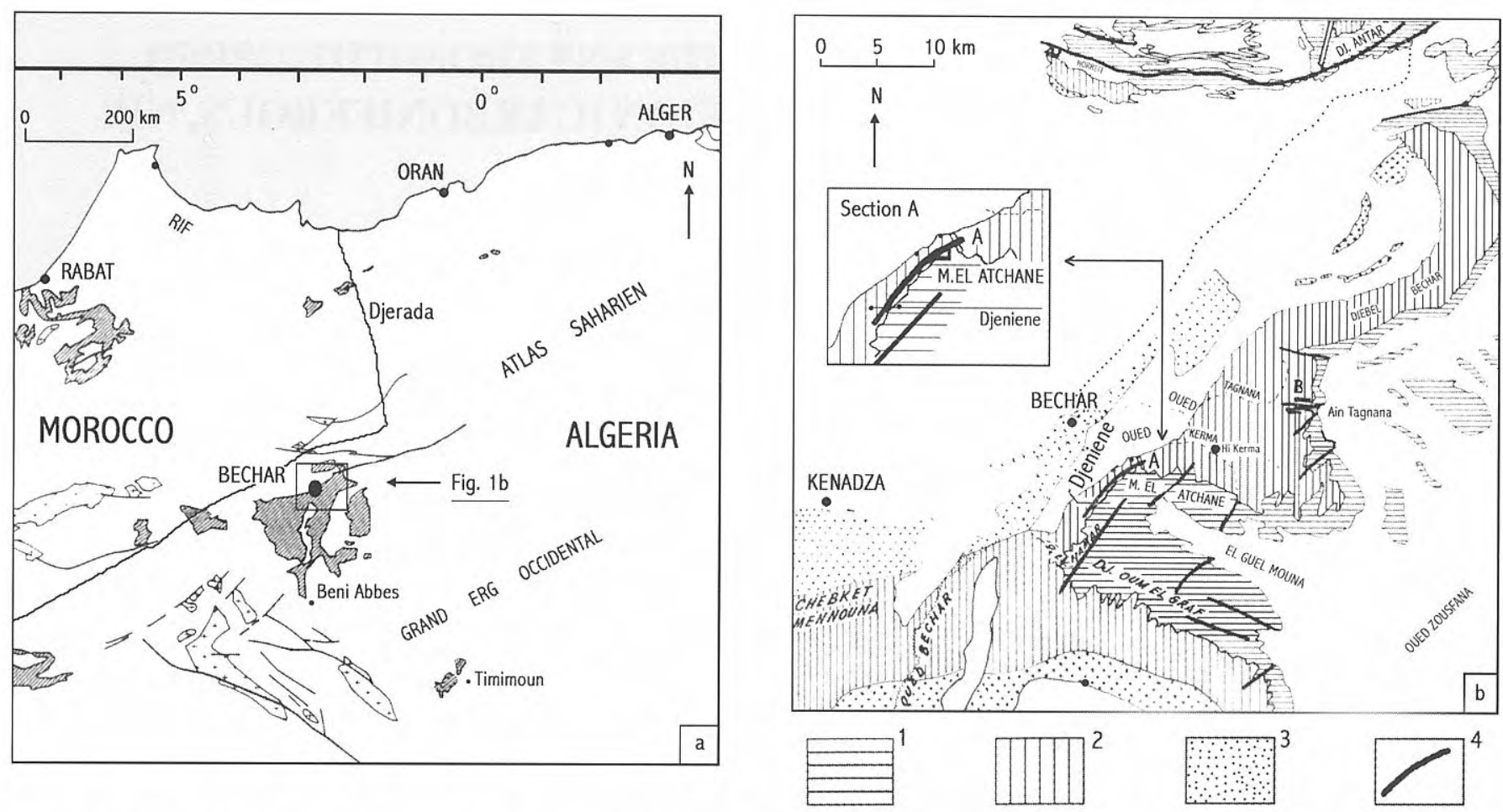

Figure 1. Geographical and stratigraphical location of the sampled section. a Modified after figure 2 of Legrand-Blain, 1986. Sketch-map showing the Carboniferous (striped area) in the Béchar Basin. The rectangle, enlarged in figure 1b, refers to the Carboniferous in the vicinity of Béchar city. b Modified after figure 1 of Legrand-Blain, 1967. Map showing section A of Legrand-Blain (see also inset) in the Djebel Béchar Group (2). Section A is close to the sampled section of the present paper.

1 = Zousfana Group (underlies the Djebel Béchar Group); 2 = Djebel Béchar Group (includes the Tagnana Formation); 3 = Kenadza Formation and the Béchar Basin coal measures (overlies the Djebel Béchar Group); $4=$ Major faults.

\section{INTRODUCTION}

The present paper describes early Bashkirian, mainly fusulinoidean foraminifera from the upper part of the Tagnana Formation near Béchar (NW Algeria) (Fig. 1), and is one of a number of reports that started with the description of an early Moscovian fusulinoidean fauna from the Kenadza Formation, followed by similar studies of the earliest Moscovian and late Bashkirian Oued el Hamar Formation and the late and early Bashkirian Hassi Kerma Formation (van Ginkel, 1986a, 1986b, 1989, 1992).

The upper part of the Tagnana Formation is also informally known as the Tagnana-III Member. The investigated sequence (about $65 \mathrm{~m}$ thick) consists mainly of shales, alternating with up to $7 \mathrm{~m}$ thick and sometimes oolitic limestone beds, and is underlain by the Tagnana-II Member. The Tagnana-II Member is a prominent limestone cliff (about $50 \mathrm{~m}$ thick). The Tagnana-I Member (approximately $150 \mathrm{~m}$ thick) at the base of the formation resembles the Tagnana-III Member, but is reported to be more arenaceous. This lower member contains the Mid-Carboniferous boundary [= first appearance of Declinognathodus noduliferus near the top of unit E of Lemosquet (Weyant, 1982)] (Fig. 2).

The Tagnana Formation underlies the Hassi Kerma
Formation and the latter is overlain by the Oued el Hamar Formation. The Tagnana, Hassi Kerma, and Oued el Hamar formations together form the Djebel Béchar Group (Pareyn, 1961). A detailed description of the sequence comprising these three formations was presented by Legrand-Blain (1967).

The sequence between the Mid-Carboniferous boundary and the base of the Djéniène Limestone (=Niveau D) at the top of the Oued el Hamar Formation appears to be a complete (Bogdanovsky-Asatausky) succession of Bashkirian rocks. However, more detailed studies have shown that sedimentation during this interval was not continuous (Lemosquet and Pareyn, 1975)

For a general description of the Carboniferous succession in NW Algeria, including the Béchar area, the studies of Pareyn (1961) and Lemosquet and Pareyn (1985) may be consulted.

\section{LOCATION OF SAMPLES}

The sampled sequence is exposed in a section eastsoutheast of Béchar, north of Mouizeb el Atchane, close to section A (Fig. 1; Legrand-Blain, 1967, fig. 1).

The present account considers foraminifera (mainly fusulinoideans) and conodonts from two sampling stations 
located 3-8 m (sample SA 11) and 50-55 m (sample SA 13) above the top of the Tagnana-II Member (Fig. 3, Appendix). In addition to SA numbers, the section in Figure 3 shows also DZ and ML numbers, which refer to samples containing brachiopods. The ML numbers refer to the collections from corresponding sites in section A of Dr. M. Legrand-Blain and the DZ numbers (of the present section) to collections of Dr. C.F. Winkler Prins. The stratigraphic position of the DZ sites, which often correspond to ML sites in the A section, helped to verify the precise positions of the present and previous foraminiferal SA sampling stations.

The brachiopods and foraminifera from the DZ and SA sampling stations were collected in 1973 and are kept at the Leiden National Museum of Natural History (The Netherlands).

\section{DISCUSSION OF THE STRATIGRAPHIC POSITION OF SAMPLES 13 AND SA 11}

Initially, we considered the alternation of shale and, often oolitic, limestone of about $65 \mathrm{~m}$ thickness underlain by the Tagnana-II Member to represent the Tagnana-III Member (Fig. 3, Appendix). At present this seems somewhat dubious. The uncertainty arose when age estimates based on forams and conodonts of the present section appeared to differ from those based on ammonoids found in a typical section of the Tagnana-III Member (e.g. section B of Legrand-Blain, 1967, fig. 1, p. 302). The analysis of the ammonoid distribution of the Tagnana-III Member by Manger et al. (1985) who report Cancelloceras only from the upper part of Tagnana III, combined with Popov's ammonoid records of the Donets Basin showing the appearance of Cancelloceras cancellatum (together with other species of this genus) from the E8 Limestone (Popov, 1979, fig. 1, p. 27), leads to the conclusion that the stratigraphic level of the Tagnana-III Member corresponds to the middle or lower part of the C1-5 (E) suite (not above the E 7 Limestone), comparable to the Siuransky (Ural Mountains), the Seslavinsky (Central Asia), or the Krasnopolyansky (Moscow Basin). A similar conclusion follows from the correlation of Carboniferous stratigraphic units of the Donets Basin and North Africa (Aisenverg et al., 1979, fig. 1,; Semichatova et al., 1979, fig. 2). Preliminary results of foraminiferal studies from several sections from the Béchar and Abadla Basins by Sebbar (1997) show, in her figure 3 , a correlation of the upper part of the Tagnana Formation with strata below the Pseudostaffella antiqua Zone of the former USSR, below Zone 21 of Mamet, and below Zone Cf9 of Conil. Sebbar's correlations agree with the aforementioned correlations. However, the foraminifera and conodonts of the present paper point to a correlation with the Upper E (E8-E9) or F1 limestones of the Donets Basin. Probably, only the basal strata of the Tagnana III Member can be correlated with the E7 limestone or the upper part of the Siuransky (Fig. 4).

If we stick to our initial opinion, that in the present section the succession (55-65 $\mathrm{m}$ ) overlying the Tagnana-

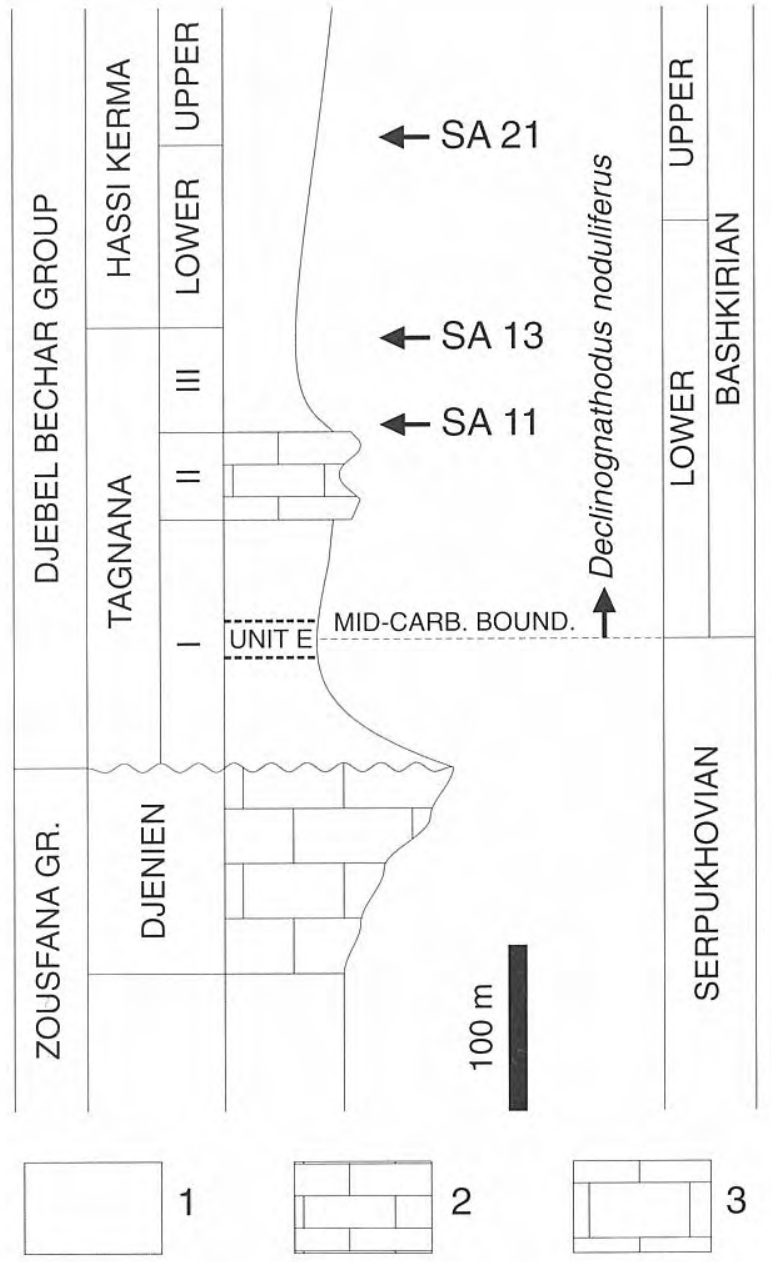

Figure 2. Stratigraphic position of the Tagnana Formation (including the sampls SA 13 and SA 11 in the Tagnana-III member).

1 = Alternation of carbonates and siliceous clastics; 2 = Carbonates; 3 = Mainly reefal and peri-reefal carbonates.

II Member represents the Tagnana-III member, this would imply that ammonoids indicate a slightly older age for the Tagnana-III member than foraminifera and conodonts. An alternative interpretation is that in the present section this basal sequence does not belong to the Tagnana-III Member, but to the lowermost part of the Hassi Kerma Formation. The hiatus at the base of the present sequence (Fig. 3) might then involve most or all of the Tagnana-III Member. On the other hand, the lithological succession of the Tagnana-III Member of the nearby section A (Fig. 1b; Legrand-Blain, 1967, fig. 1) compares rather closely with the present sequence.

\section{DIFFICULTIES REGARDING IDENTIFICATION}

Mainly during the second half of the last century, hundreds of new, notably Eurasian, eostaffellids and primitive ozawainellids were described; see Maslo and Vachard (1997) for complete lists of species. Discrimination between species was based on very small 


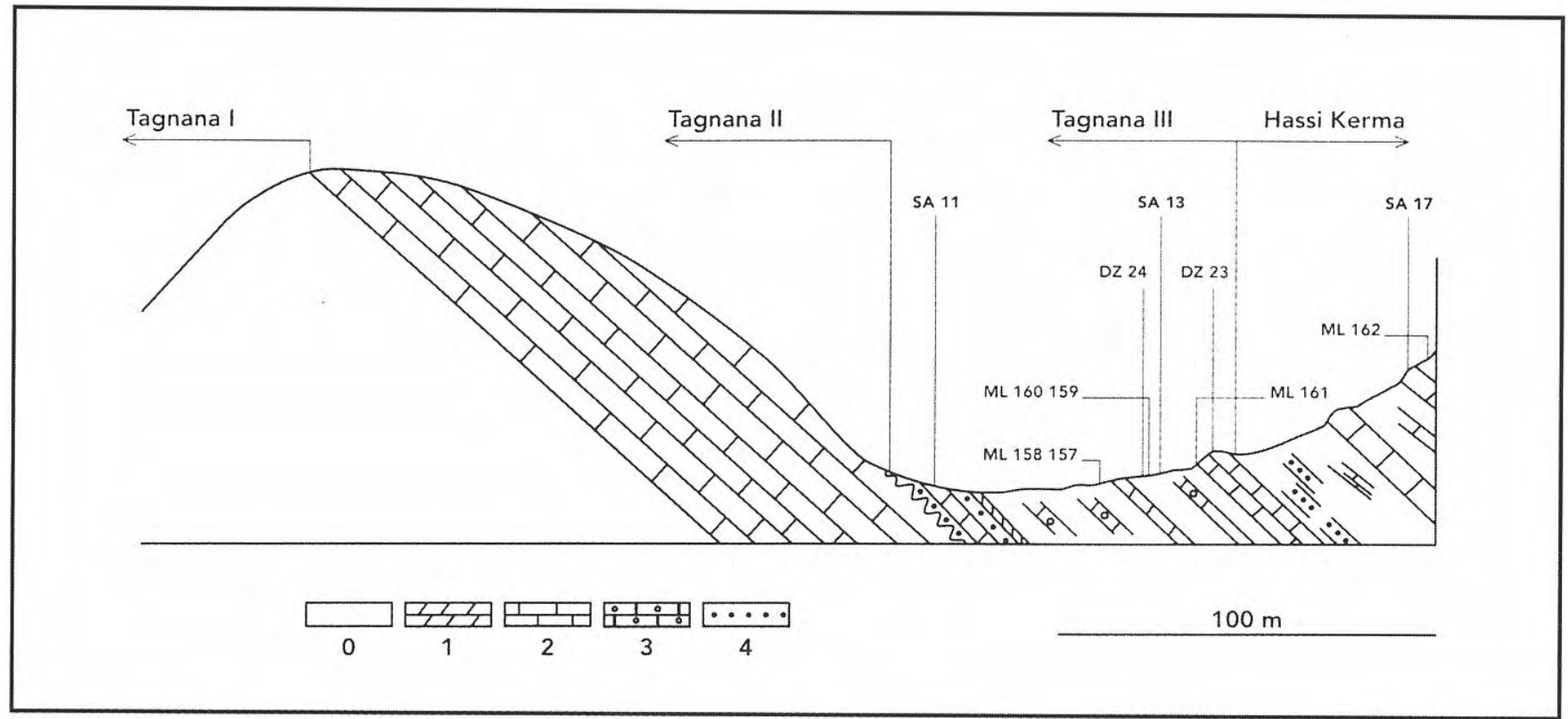

Figure 3. Position of samples SA 13 and SA 11 in the upper member (Tagnana-III) of the Tagnana Formation in the measured stratigraphic section. $0=$ Poorly exposed (mainly shale); $1=$ Dolostone $2=$ Limestone; $3=$ Oolitic limestone; $4=$ Sandstone and quarzitic sandstone.

differences which do not allow for much variation within a species. However, the written descriptions of new species suggested considerable variability and overlap with other species. Lamentably, the impression of conspicuous variability was generally not confirmed by a sufficient number of illustrations of specimens accompanying the descriptions; in quite a number of cases not more than three specimens were shown. Generally all specimens were axial sections with little attention paid to sagittal sections. The lack of knowledge on the degree of variability of a species in a sample and consequently the number of species it contains, may generally have impeded proper identifications. More illustrations of paratypes of a new species might have facilitated subsequent identifications, and could have improved the understanding of relationships with other species.

These difficulties also complicated the present studies on the Algerian eostaffellids (in particular with regard to the genera Eostaffella and Millerella), which seldom resulted in unambiguous identifications; uncertainties remained at species and genus level. Actually, some of the groups of specimens considered distinct from each other may be conspecific. A more profound analysis using more material could have shown the coalescing of groups which at the present stage appear to be still separated. Investigations into this latter problem ended prematurely when the sampling material had been exhausted. The foraminiferal identifications from the two samples SA 13 and SA 11 are based on 157 slides of fairly rich limestone and are listed on p. 42 and p. 43 respectively.

As mentioned above, the distinction between the genera Millerella Thompson, 1942 and Eostaffella Rauzer-Chernousova, 1948b was another problem.
According to descriptions of the type species Millerella marblensis Thompson and Eostaffella parastruvei (Rauzer-Chernousova), the features by which these species can be distinguished are:

\section{Millerella marblensis}

(a) Coiling is evolute in the outer (two) whorl(s); specimens may become uncoiled in the adult stage.

(b) Chomata are discontinuous (after Moore, 1964).

(c) Spirotheca consists of three layers: upper tectorium, tectum, and a clear layer below the tectum.

(d) A tunnel, typical for fusulinids, is present (after Moore, 1964).

\section{Eostaffella parastruvei}

(a) Coiling is usually accepted as being involute.

(b) Secondary deposits are in the form of pseudochomata (Rauzer-Chernousova, 1948b); this suggests a weaker development of these deposits, by comparison with Millerella marblensis.

c) Wall dark, finely granular, undifferentiated or composed of a thin tectum and inner and outer tectoria (Rauzer-Chernousova, 1948b).

(d) A [primary] aperture is present (Armstrong and Mamet, 1977). The assignment by Armstrong and Mamet of the genera Millerella and Eostaffella to different families (Ozawainellidae and Eostaffellidae, respectively) was probably based on this difference.

However, none of the differences "a" to "c" suffice to distinguish between Eostaffella and Millerella or lead to the establishment of a natural classification:

\section{(a) Coiling}

The slightly oblique section of the type specimen of Eostaffella parastruvei does not permit to conclude that 


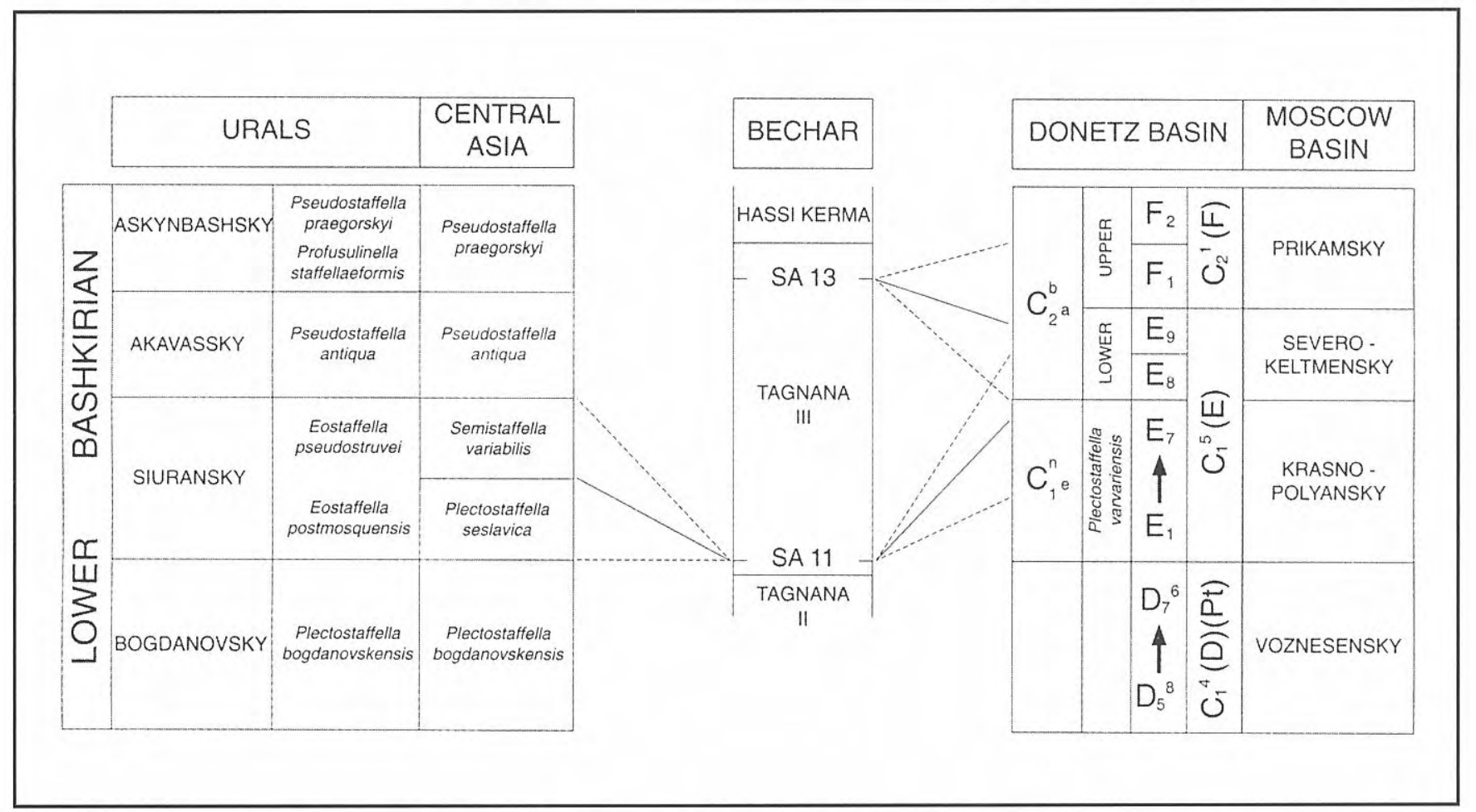

Figure 4. Upper and lower Tagnana-III beds at sampling localities SA 13 and SA 11 correlated with East European and Central Asean (bio)stratigraphic units. Correlations are based on foraminifera and conodonts. Full-drawn lines represent the most likely correlations, dashed lines the extreme possibilities. Stratigraphic data regarding the lowermost Bashkirian are partly based on Nemyrovska (1999, fig. 36).

the final whorl is involute. However, even if fully involute coiling could be confirmed, Eurasian Lower Carboniferous (partially) evolute species should preferably be assigned to Eostaffella, because they are probably not closely related to typical Millerella.

(b) Chomata

The species groups of Eostaffella ikensis Vissarionova, 1948, and Eostaffella mirifica Brazhnikova in Brazhnikova et al., 1967, are considered typical Eostaffella. However, species of these groups show usually ribbon-like chomata (low and relatively wide), that are different from the pseudochomata of the type species of Eostaffella.

(c) Wall structure

A three-layered wall comparable to that of the type species of Millerella has usually been recorded as well for species which on the basis of their involute coiling were assigned to Eostaffella. Moreover, "the holotype of Eostaffella parastruvei shows a differentiated wall"... and "preservation (or lack thereof) may prevent recognition of layering in some species" (Dr. P. Brenckle, written communication).

(d) Aperture

A fundamental distinction between Eostaffella and Millerella on the basis of aperture versus tunnel is perhaps possible. However, it is not yet clear which of the involute species usually assigned to Eostaffella have indeed a primary aperture. Bashkirian or Moscovian Eostaffella showing well-established chomata resembling Ozawainella have more likely a tunnel.
Today, a generic diagnosis of Eostaffella and Millerella (as based on their type species) briefly summing up their characteristics - and (implicitly) their differences - cannot be easily established. Neither of the three characters, a-c, can be applied separately for the definition of the two genera if the resulting classification should correspond to accepted phylogenetic relationships. Nevertheless, these and other characters (i.e. shape of test, septal count/shape, degree of skewness of coiling) could be used in different combinations. Various specific combinations, each defining related groups of species, might together be sufficient to discriminate between the two genera. It may be also useful to consider the introduction of a new genus for most of the species included in Zellerinella Mamet, 1981 (see Armstrong and Mamet, 1977). Unfortunately, the genus Zellerinella is not generally accepted because of the apparently close similarity between the type species of Zellerinella and that of Endostaffella (Brenckle and Groves, 1981; Rich, 1986). Another possibility might be to reintroduce Paramillerella Thompson, 1951 (see Anisgard and Campau, 1963, and Brenckle and Groves, 1981; the latter paper suggests a relationship between Endostaffella and Paramillerella).

The present account deals with species of the groups of Eostaffella pseudostruvei (Rauzer-Chernousova and Belyaev, 1936), and Eostaffella chomatifera Kireeva, 1951. In this and my previous papers on Algerian fusulinoideans, these species were not included in Eostaffella because they seem to be only remotely related 
to the typical (Upper Viséan-Serpukhovian) species of Eostaffella. Provisionally, they are assigned to Millerella for reasons of priority. Actually, these species may be closer to the type species Millerella? advena Thompson, 1944 of Paramillerella. Typical and/or topotypical material of this species should be restudied. That applies to Eostaffella parastruvei as well.

\section{MAIN ASPECTS OF THE DESCRIBED FORAMI- NIFERA}

The foraminifera from the upper part of the Tagnana Formation are of Lower Bashkirian age, and especially similar to foraminifera from the Donets Basin found in the upper part of the E suite. The forms that prevail near the top of the Tagnana III Member (sample SA 13) are species of the group of Millerella acutissima (Kireeva, 1949), whereas towards the base of this member (sample SA 11) the most common forms belong to the group of Millerella pseudostruvei (Rauzer-Chernousova and Belyaev, 1936). These forms are found together with species of the group of Millerella chomatifera (Kireeva, 1951). (Millerella close to the type species Millerella marblensis Thompson, 1942, have not been found, neither in the Tagnana Formation nor in the other formations of the Djebel Béchar Limestone Group). Typical species of the genus Plectostaffella such as Plectostaffella jakhensis (Reitlinger, 1971) do not occur above the lower part of the Tagnana III Member, whereas species close to Plectostaffella varvariensis (Brazhnikova and Potievska, 1948) are present not only at the base of the Tagnana III Member but are also found in the lower part of the overlying Hassi Kerma Formation. A few forms from samples SA 13 and SA 11 have been assigned to Pseudonovella although they resemble not only Pseudonovella ex gr. carbonica (Grozdilova and Lebedeva, 1950), but also Millerella ex gr. pseudostruvei and Millerella grozdilovae (Maslo and Vachard, 1997). Typical Eostaffella, well-known from Upper Viséan and Serpukhovian strata, are either absent (SA 13) or fairly rare (SA 11). Two specimens from sample SA 11 were compared with Eostaffellina libera (Rumyantseva, 1970). A closely similar form occurs in the lower part of the Hassi Kerma Formation. However, both species clearly differ from typical Serpukhovian or Upper Viséan Eostaffellina and might not be congeneric with the earlier forms of Eostaffellina. Equally dubious is the presence of Endostaffella in the Tagnana III Member (SA 11); the specimens could be descendants from typical Viséan and Serpukhovian species, but the possibility that they represent young individuals of Millerella ex $\mathrm{gr}$. pseudostruvei seems more likely. Pseudostaffella antiqua (Dutkevitch, 1934) was expected to be present, because its occurrence in the Tagnana III Member had been established already by Lys (cf. Lys 1976, 1979, 1985). Yet, the genus Pseudostaffella is apparently absent at sample SA 11, whereas locality SA 13 yielded only a single specimen of the primitive form Pseudostaffella (Semistaffella) variabilis Reitlinger, 1961.

\section{BIOSTRATIGRAPHY}

\section{CORRELATIONS BY FORAMINIFERA AND CONODONTS FROM SAMPLE SA 13}

\section{Foraminifera}

Sample SA 13 yielded eight fusulinoidean species: Pseudostaffella (Semistaffella) cf. variabilis Reitlinger, 1961, Pseudonovella spp., Millerella spp. cf. M. paracarbonica Manukalova et al., 1969, Millerella ex gr. acutissima (Kireeva, 1949), Millerella ex gr. chomatifera (Kireeva, 1951), and Mediocris breviscula (Ganelina, 1951). These species have been compared with similar species from the Donets Basin mainly after data of Manukalova et al. (1969) and Vachard and Maslo (1996). Examination of the distribution of Donets Basin fusulinoidean species in a succession of biozones shows that seven Algerian species from SA 13 are close to or conspecific with species that occur in the C2b-a Zone. Higher and lower biozones share progressively fewer species with the SA 13 assemblage. A more precise comparison of the stratigraphic ranges of Donets species close to or conspecific with species of the SA 13 assemblage indicates the upper part of the C2b-a Zone (Table 1, Fig. 4).

The oldest possible stratigraphic level of SA 13, on the basis of the presence of Pseudostaffella (Semistaffella) variabilis, is the E5 Limestone (C1n-e Zone) (see Vachard and Maslo, 1996). It is important to note that Pseudostaffella (Pseudostaffella) antiqua (Dutkevich, 1934) has not been found in sample SA 13. The absence of Pseudostaffella (Pseudostaffella) at SA 13 is either fortuitous or points to a zone lower than the C2b-a Zone (lower part). However, this species was reported to be present in this part of the Tagnana Formation by Lys (1976, 1979, 1985). Its presence clearly distinguishes the C2b-a Zone (lower part) from assemblages of lower zones. The upper part of the Tagnana Formation, according to Mamet et al., 1995, fig. 5, corresponds to Mamet's Zone 21 and Conil's Zone Cf 9. This agrees with the results of Lys mentioned above.

Considering all fusulinoidean evidence, the equivalent stratigraphic level of sample SA 13 in the Donets Basin is estimated to be not below the E8 Limestone [(C1-5 (E) suite] and not above the F1 Limestone [C2-1 (F) suite].

\section{Conodonts}

A preliminary investigation of conodonts by van den Boogaard yielded the following species: Idiognathoides sinuatus, Idiognathoides corrugatus, Idiognathoides macer, and Declinognathodus lateralis. It was concluded that the condonts from sample SA 13 indicate the Idiognathoides sinuatus Zone, and that the assemblage may occur in the Krasnopolyansky and the Severokeltmensky of the Moscow Basin (Dr. M. van den Boogaard, written communication, early 1990's).

The Idiognathoides sinuatus Zone in the Donets Basin 


\begin{tabular}{lllll}
\hline Biozone & + & - & $\mathrm{o}$ & $\mathrm{n}=7$ \\
\hline C2b-b & 5 & 1 & 1 & \\
C2b-a(upper part) & 3 & 3 & 1 & \\
C2b-a(lower part) & 0 & 5 & 2 & \\
\hline
\end{tabular}

Table 1. Foraminiferal content of sample SA 13 (seven species) compared with a succession of biozones in the Donets Basin. $+=$ the number of species that occur more likely in a zone below the biozone considered. $-=$ the number of species that occur more likely in a zone above the biozone considered. $\mathrm{o}=$ the number of species that do not occur more likely in higher or lower biozones than the biozone considered; this includes, as a special case, an occurrence restricted to the biozone.

extends from the E1 Limestone up to and including the F1/1 Limestone. (Nemyrovskaya, 1982, fig. 1).

Recent re-examination of the same collection by Nemyrovska resulted in the following identifications: Declinognathodus lateralis, Declinognathodus lateralis($>$ Decl. pseudolateralis), Idiognathoides sinuatus, Idiognathoides corrugatus, Idiognathoides sulcatus parvus, Idiognathoides macer(?), Idiognathodus sp. (early form, resembles Streptognathodus nodosus of Higgins, 1975), Aethotaxis advena (A1a+ A1b elem. + A2). This assemblage indicates either the uppermost part of the C1-5 (E) suite or some level of the C2-1 (F) suite of the Donets Basin (Dr. T.I. Nemyrovska, written communication, 1998).

\section{Correlations with the Donets/Moscow Basins (summarized)}

Foraminifera: E8-F1 Limestone Formations of Donets Basin.

Conodonts: Krasnopolyansky or Severokeltmensky (M. van den Boogaard).

E9 or F Limestones (upper part Severokeltmensky or Prikamsky) (T.I. Nemyrovska).

\section{CORRELATIONS BY FORAMINIFERA AND CONODONTS FROM SAMPLE SA 11}

\section{Foraminifera}

The fusulinoideans (and a few other foraminifera) from sample SA 11 have been compared with similar species from the Donets Basin, Urals and Central Asia. The sampling locality yielded the following species. Pseudoendothyra ex gr. struvii (von Möller, 1879), Pseudonovella spp., Millerella cf. pseudostruvei (RauzerChernousova and Belyaev, 1936), Millerella angusta (Kireeva, 1951), Millerella yugorskensis (Solovieva, 1984), Millerella spp. ex gr. Millerella pseudostruvei, Millerella ex gr. chomatifera (Kireeva, 1951), Millerella cf. paraumbilicata Manukalova et al., 1969, Millerella

\begin{tabular}{lrrrr}
\hline Biozone & + & - & o & $\mathrm{n}=19$ \\
\hline C2b-b & 17 & 0 & 2 & \\
C2b-a (upper part) & 14 & 2 & 3 & \\
C2b-a (lower part) & 9 & 3 & 7 & \\
C1n-e & 2 & 12 & 5 &
\end{tabular}

Table 2. Foraminiferal content of sample SA 11 (nineteen species) compared with a succession of biozones in the Donets Basin. Explanation of symbols as in Table 1 .

aff. paraumbilicata, Plectostaffella aff. varvariensis (Brazhnikova and Potievska, 1948), Plectostaffella jakhensis (Reitlinger, 1971), Plectostaffella? sp., Eostaffellina cf. libera (Rumyantseva, 1970), Eostaffella ex gr. parastruvei (Rauzer-Chernousova, 1948b), Eostaffella aff. chusovensis Kireeva, 1951, Endostaffella? sp., Mediocris breviscula (Ganelina, 1951), Eolasiodiscus aff. donbassicus Reitlinger, 1956 [single specimen: $11 / 36(5)]$.

\section{Comparison with the Donets Basin}

Mainly after data provided by Manukalova et al. (1969) and Vachard and Maslo (1996).

Of the nineteen species from sample SA 11 that may also occur in the Donets Basin, twelve to seventeen are close (or conspecific) to some species occurring in the biozones C1n-e, C2b-a (lower part), C2b-a (upper part), or $\mathrm{C} 2 \mathrm{~b}-\mathrm{b}$. This corresponds to the fusulinoideans found in the C1-5 (E), C2-1 (F) and C2-1 (G) suites. This high number of shared similar species drops rapidly for higher and lower biozones (i.e. seven in $\mathrm{Cln}$-d Zone and four in C2b-c Zone). A closer examination of the distribution of species from the Donets Basin close to species of the SA 11 assemblage, indicates rather the C1-5 (E) suite [either Zone C1n-e or Zone C2b-a Zone (lower part)] for the SA 11 assemblage (Table 2, Fig. 4).

Zone C2b-a (lower part) typically contains Pseudostaffella (Pseudostaffella) antiqua which belongs to the more evolved part of the assemblage of species from this zone. However, neither this species nor species of Pseudostaffella (Semistaffella) were found in sample SA 11. In view of the absence of these more evolved species, the stratigraphic level indicated by sample SA 11 is estimated to be below the Mandrykinskaya group of the Donets Basin [the latter are a group of very persistent limestones comprising the interval E9-F1(1)], which may correspond to a level low in the Severokeltmensky Horizon of the Moscow Basin. Correlation with a high level of the Krasnopolyansky is also possible.

\section{Comparison with the Urals and Central Asia}

Mainly after data of Sinitsyna and Sinitsyn (1987), Groves (1988), and Kulagina et al. (1992).

A comparison of fusulinoideans from sample SA 11 with corresponding assemblages from the Urals (southern part, west slope), and Central Asia (Tien-Shan Mountains) shows that out of a total of twenty-three 


\begin{tabular}{|c|c|c|c|c|c|}
\hline "Horizon" & Biozone* & + & - & o & $\mathrm{n}=23$ \\
\hline Akavassky & Ps. antiqua & 16 & 2 & 5 & \\
\hline Siuransky & Semist. variabilis & 8 & 5 & 10 & \\
\hline Siuransky & Plect. seslavica & 4 & 8 & 11 & \\
\hline Bogdanovsky & $\begin{array}{c}\text { y Plect. bogdanovkensis } \\
\text { (Upper subzone) }\end{array}$ & s 0 & 11 & 12 & \\
\hline Bogdanovsky & $\begin{array}{c}\text { y Plect. bogdanovkensis } \\
\text { (Lower subzone) }\end{array}$ & 0 & 18 & 5 & \\
\hline
\end{tabular}

Table 3. Foraminiferal content of sample SA 11 (twentythree species) compared with a succession of biozones in Central Asia. Explanation of symbols as in Table 1. * Biozones for Southern Urals and Central Asia after Kulagina et al., 1992.

species from SA 11, a vast majority (seventeen to twentyone) are conspecific or closely similar to some Asian or Uralian species occurring in the zones of Pseudostaffella antiqua, Semistaffella variabilis, Plectostaffella seslavica and Plectostaffella bogdanovkensis (AkavasskyBogdanovsky). This high number of conspecific or close forms decreases to eleven to thirteen in the overlying Pseudostaffella praegorskyi Zone (Askynbashky) and the underlying zones of Plectostaffella posochovae and Eosigmoilina explicata (Ustsarbaisky). A closer examination of the stratigraphic ranges of the Bashkirian, Ural, and Asian species that are similar to the identified Algerian forms indicates the Plectostaffella seslavica and Semistaffella variabilis zones (Table 3, Fig. 4).

Results may be summarized as follows. Comparison of the assemblage from SA 11 with the Donets fusulinoideans points to the C1-5 (E) suite (not above the E8 Limestone), whereas a comparison with Bashkiria, S Urals, and Central Asia indicates the Siuransky Horizon.

\section{Conodonts}

Sample SA 11 contains the following species: Declinognathodus noduliferus, Declinognathodus lateralis, and Idiognathoides aff. corrugatus. This assemblage possibly indicates the Declinognathodus noduliferus Zone. However, one of the species present is reminiscent of Idiognathodus corrugatus. The present association probably points to a low level in the zone which overlies the Declinognathodus noduliferus Zone. Age: Krasnopolyansky or Severokeltmensky" (Dr. M. van den Boogaard, written communication, early 1990's).

Recently, the same collection was investigated again by Nemyrovska who identified Declinognathodus lateralis, Declinognathodus noduliferus, Declinognathodus lateralis (-> Decl. pseudolateralis), Idiognathoides corrugatus, Hindeodus minutus, and Aethotaxis sp. (A1 elem.), and concluded as follows: "this association of species belongs to the Idiognathodus corrugatus Zone and indicates the upper E Formation (Donets Basin) and uppermost part of the Krasnopolyansky or Severokeltmensky (Moscow Basin)" (Dr. T.I. Nemyrovska, written communication, 1998).

\section{Correlations with the Donets Basin, Moscow Basin, Urals and Central Asia (summarized)}

Foraminifera: High level in E Suite of Donets Basin, about E7 or E8 Limestone (= upper Krasnopolyansky or lower Severokeltmensky of Moscow Basin).

Siuransky/Seslavinsky of Ural/Central Asia (= middle to upper Krasnopolyansky of Moscow Basin).

Conodonts: Krasnopolyansky or Severokeltmensky (van den Boogaard).

Upper E Suite (Donets Basin), or uppermost Krasnopolyansky to Severokeltmensky (Moscow Basin) (Nemyrovska).

\section{DESCRIPTION OF SPECIES}

Abbreviations used in the tables of measurements: No.wh. $=$ Number of whorls; $\mathrm{D}(0)=$ Diameter of proloculum; $\mathrm{D}(2), \mathrm{D}(3)=$ Diameter second and third whorl of test respectively; $\mathrm{D}=$ Diameter of test; $\mathrm{L} / \mathrm{D}=$ Length/Diameter ratio of test; F.r.= Form ratio of test, and R.v.= Radius vector of test; W.th.= wall thickness of test; $m=$ mean; $s=$ standard deviation; $\mathrm{n}=$ number of measurements.

Measurements of $\mathrm{D}(0), \mathrm{D}(2), \mathrm{D}(3)$, D, R.v., and W.th. are in microns.

Pseudoendothyra Mikhailov, 1939

Type species: Fusulinella struvii von Möller, 1879.

$$
\begin{gathered}
\text { Pseudoendothyra ex gr. struvii (von Möller, } \\
\text { 1879) } \\
\text { Fig. } 5 \mathrm{r}, \mathrm{s}
\end{gathered}
$$

Sample: SA 11.

Measurements:

Specimen No.wh. D $(0)$ D L/D W.th. R.v. F.r. 21(7)(ax.) 4 or $4.5 \quad-\quad \begin{array}{llllll}536 & 0.53 & 14 & 284 & 0.50\end{array}$ 29(7)(sag.) 4.5 or $5 \quad-\quad 588 \quad 17 \quad 312$

Number of septa of the three last whorls (counting from the antetheca of the ultimate whorl) is $19,17,13$ respectively.

\section{Description}

Shape thickly lenticular to subrhomboidal; lateral sides straight or slightly convex; periphery of inner whorls probably arched, and in outer whorl bluntly pointed to arched. Chomata seem to be weakly developed. Tunnel is wide. Indistinct mural pores can be observed in outer whorls. Straight or somewhat curved septa are perpendicular to the wall or slightly forwardly inclined.

\section{Comparisons}

If indeed the two specimens are adults, they represent a small species resembling Pseudoendothyra struvii, $P$. 

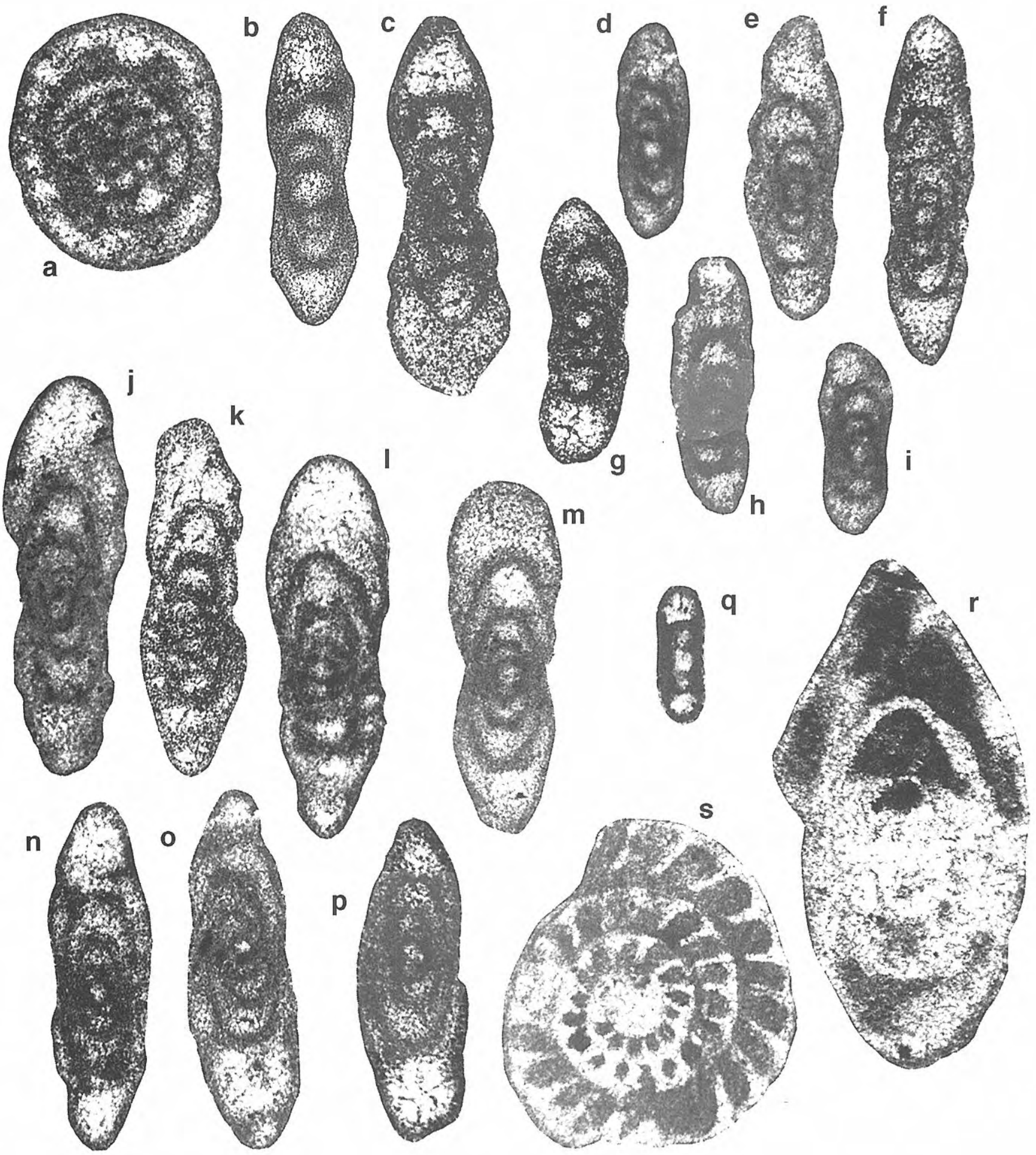

Figure 5. a. Pseudostaffella (Semistaffella) cf. variabilis Reitlinger, 1961 specimen 13/8(1); b. Pseudonovella sp. 1, specimen 13/54; c. Pseudonovella sp. 2, specimen 13/55(1); d-i. Millerella sp.1 aff. M. paracarbonica Manukalova et al.,1969, specimens d. 13/18(1), e. 13/75, f. 13/49, g. 13/72, h. 13/59(2), i. 13/47(1); j-p. Millerella sp.2 aff. M. paracarbonica Manukalova et al.,1969, specimens j. 13/28(1), k. 13/63(3), 1. 13/11(1), m. 13/82, n. 13(63(2), o. 13/69(1), p. 13/6(1); q. Mediocris breviscula (Ganelina, 1951), specimen 13/3(4); r,s. Pseudoendothyra ex gr. struvii (von Möller, 1879), specimens r. 11/21(7), s. 11/29(7). Axial sections x160, sagittal section x100. Specimens a-q: SA $13 ; \mathbf{r}, \mathbf{s}:$ SA 11.

struvii suppressa (Shlykova, 1951), P. afflientia (Durkina, 1959), and P. intermedia (Shlykova, 1951). These species have been described from much older (= Viséan) strata than the Tagnana-III beds. Somewhat similar is also
Pseudoendothyra opinata (Grozdilova and Lebedeva, 1954) from the Bashkirian. The aforementioned species usually show a diaphanotheca, not observed in the present specimens, perhaps due to alteration of the wall. 


\section{Pseudostaffella Thompson, 1942}

Type species: Pseudostaffella needhami Thompson, 1942.

Pseudostaffella (Semistaffella) Reitlinger, 1971

Type species: Pseudostaffella variabilis Reitlinger, 1961.

\section{Pseudostaffella (Semistaffella) cf. variabilis Reitlinger, 1961 \\ Fig. 5 a}

\section{Sample: SA 13.}

\section{Measurements:}

Specimen No.wh. D(0) D(2) D(3) D L/D W.th. R.v. F.r. $\begin{array}{llllllllll}8(1) & 3.5-4 & - & - & - & 285 & 0.83 & 13 & 160 & 0.73\end{array}$

\section{Comparisons}

The Algerian specimen resembles the holotype (the only illustrated specimen) of Pseudostaffella (Semistaffella) variabilis. Very similar is also Pseudostaffella (Semistaffella) minuta Sada, 1975, which in comparison with Pseudostaffella (Semistaffella) variabilis has more volutions (up to four versus up to three) and a smaller L/D ratio (0.7-0.8) versus 0.8-1.0). Both species may be slightly larger than the Algerian species. The similarity between Pseudostaffella (Semistaffella) minuta and Pseudostaffella (Semistaffella) variabilis - Groves (1988) considers them conspecificmakes it difficult to decide to which species the Algerian specimen should be assigned; Pseudostaffella (Semistaffella) variabilis is preferred here for reasons of priority. Pseudostaffella (Semistaffella) variabilis from the Bashkirian stratotype (cf. Groves, 1988, fig. 4, figs. 17.22-17.29) differs from the Algerian form by its oval/nautiloid shape (smaller L/D ratio) and greater shell diameter. Less similar is Eostaffellina protvae (RauzerChernousova, 1948a), which differs in the more primitive character of its chomata and slightly greater shell diameter.

\section{Pseudonovella Kireeva, 1949, emend. here}

1949 Novella (Pseudonovella) Kireeva, 27.

1951 Eostaffella (Seminovella) Rauzer-Chernousova, 64-66.

1963 Millerella Thompson (part); Rozovskaya, 110.

1963 Pseudonovella Kir.; Rozovskaya, 111-112.

Type species: Novella (Pseudonovella) irregularis Kireeva, 1949.

\section{Definition and relationship}

The differences between Seminovella RauzerChernousova and Pseudonovella are not evident, and were not discussed when Seminovella was introduced. The synonomy of Pseudonovella and Seminovella was suggested earlier (van Ginkel, 1987, p. 206, foot-note).

Pseudonovella is defined as typically comprising species of small or medium size, of discoidal shape, showing umbilical depressions and a broadly arched peripheral rim in the inner whorls, which usually becomes more pointed in outer whorls. There are at least two (partially) evolute inner whorls; outer whorl(s) often show a trend towards involute coiling.

Pseudonovella is related to Millerella but differs from Millerella in its evolute coiling in two or more initial whorls and in its more embracing outer whorl(s), contrary to the usually involute inner whorls and the clearly evolute outer whorl(s) of Millerella. The genus Pseudonovella is also related to "Eostaffella" ex gr. pseudostruvei (Rauzer-Chernousova and Belyaev, 1936) and "Eostaffella" ex gr. mutabilis Rauzer-Chernousova, 1951 (e.g. "Eostaffella" grozdilovae Maslo and Vachard, 1997). The prolongation of the initial evolute stage to later whorls eventually leads to species of Pseudonovella that are intermediate between this genus and the fully evolute Novella Grozdilova and Lebedeva, 1950.

\section{Stratigraphic range}

Bashkirian-Lower Permian. Notably Upper BashkirianLower Moscovian.

\section{Species content and subdivision in groups of species}

The species assigned to Pseudonovella (including Seminovella) are subdivided in five groups of similar species as follows:

1. Pseudonovella ex gr. carbonica (Grozdilova and Lebedeva, 1950):

Millerella vivax Solovieva, 1991, M. symmetrica Manukalova et al., 1969, Eostaffella (Millerella) carbonica, E. (Seminovella) keltmensis RauzerChernousova, 1951, Millerella (Seminovella) fragilis Vakarchuk in Brazhnikova et al., 1967, M. (S.) donetziana Potievskaya, 1964, M. paraconcinna Manukalova et al., 1969, Eostaffella dolixa Manukalova, 1950, and E. lativoluta Reitlinger, 1961.

Species small or of medium size. Inner whorls clearly evolute; outer whorl in contact or sometimes slightly evolute. Umbilical depressions conspicuous.

Bashkirian-Lower Permian.

2. Pseudonovella ex gr. elegantula (RauzerChernousova, 1951):

Novella? aperta Grozdilova and Lebedeva, 1950, Eostaffella (Millerella) variabilis Rauzer-Chernousova, 1951, Millerella nataliae Maslo, 1993, Eostaffella (Seminovella) elegantula, and E. (Millerella) uralica Kireeva, 1951.

Species small to fairly large. Often deep and wide umbilical depressions. Secondary deposits absent or more commonly in the form of pseudochomata. These species differ from species of the carbonica group in the generally more widely arched periphery of the outer volutions. The outer volution is evolute, often showing wide semi-lunar chambers in axial section. In contrast, outer volutions in the carbonica species group are usually in contact.

Lower Bashkirian-Lower Moscovian. 


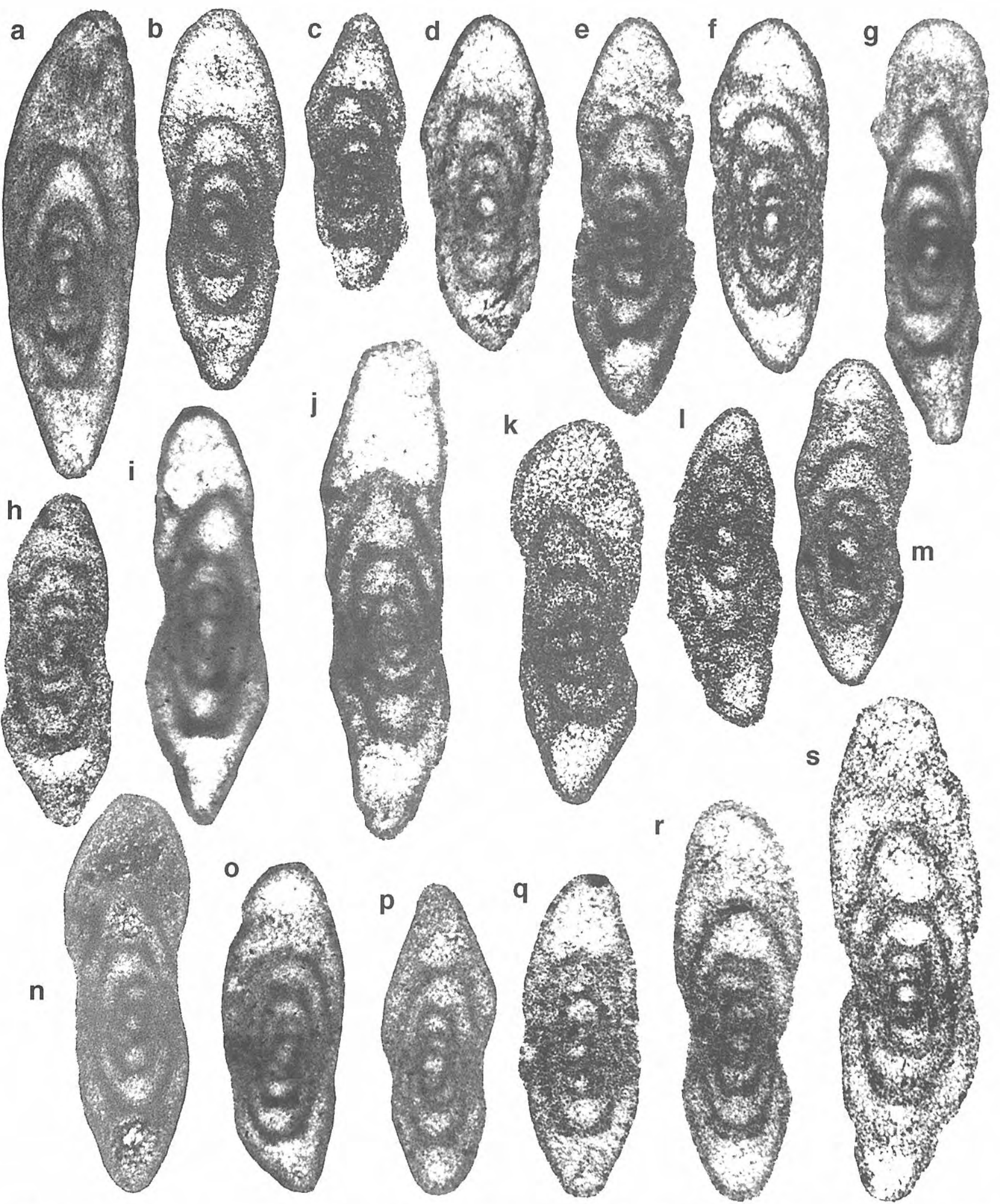

Figure 6. Millerella ex gr. acutissima (Kireeva, 1949), specimens a. 13/24, b. 13/73, c. 13/71(2), d. 13/11(2), e. 13/80, f. 13/7(1), g. 13/15(1), h. 13/51, i. 13/79, j. 13/52(2), k. 13/48, 1. 13/83, m. 13(71(1), n. 13/52(1), o. 13/65(1), p. 13/39, q. 13/55(2), r. 13/66, s. 3/11(3). Axial sections. All x160 (SA 13).

3. Pseudonovella ex gr. monstrosa Kireeva, 1949:

Novella (Pseudonovella) monstrosa, Millerella minuta Sheng, 1958, Eostaffella compressa Brazhnikova, 1951, E. depressa Putrya, 1956, and Millerella (M.) carbonifera
Rozovskaya, 1975.

Species are extremely small. Few volutions. Proloculum often large with respect to diameter of shell. Upper Bashkirian-Moscovian; mainly Moscovian. 
4. Pseudonovella ex gr. sandersoni (King, 1984):

Millerella graciosa Manukalova et al., 1969, and M. sandersoni King, 1984.

Very slender species resembling Pseudonovella irregularis and $P$. monstrosa in their small size. Close to Millerella.

Upper Lower Bashkirian-basal Upper Bashkirian (Eurasia) and upper part Marble Falls Formation North America.

5. Pseudonovella ex gr. irregularis Kireeva, 1949.

Novella (Pseudonovella) irregularis, Eostaffella nautiloides Manukalova, 1950, Pseudonovella venusta Ryazanov, 1958, and Millerella megasphaerica Chen and Wang, 1983.

These species differ from Pseudonovella ex gr. monstrosa by their somewhat larger size and generally more pointed periphery in outer volutions.

Upper Bashkirian-Lower Permian.

\section{Pseudonovella sp. 1}

Fig. 5 b

Sample: SA 13.

Measurements:

Specimen No.wh. D(0) D(2) D(3) D L/D W.th R.v. F.r. $\begin{array}{llllllllll}54 & 3 & 50 & 192 & 344 & 344 & 0.29 & 11 & 188 & 0.26\end{array}$

\section{Comparisons}

The single specimen present differs from Pseudonovella aperta (Grozdilova and Lebedeva, 1950) in its slightly more compressed shell, and more narrowly rounded or even subacute periphery. In this respect, Pseudonovella irregularis Kireeva, 1949, Millerella grozdilovae (Maslo and Vachard, 1997) (=Eostaffella acuta Grozdilova and Lebedeva, 1950), and a specimen assigned to Eostaffella acuta Grozdilova and Lebedeva, 1950, by Manukalova et al. (1969, pl. VIII, fig. 21, p. 115) are more similar than Pseudonovella aperta.

\section{Pseudonovella sp. 2}

Fig. 5 c

Sample: SA 13.

Measurements:

Specimen No.wh. D(0) D(2) D(3) D L/D W.th R.v. F.r. $\begin{array}{llllllllll}55(1) & 4-4.5 & 26 & 124 & 220 & 420 & 0.32 & 8 & 220 & 0.31\end{array}$

\section{Comparisons}

The specimen may belong to the group of Pseudonovella carbonica (Grozdilova and Lebedeva, 1950) and is somewhat similar to Pseudonovella donetziana (Potievskaya, 1964) and Pseudonovella fragilis (Vakarchuk in Brazhnikova et al., 1967). Another possibly related species is Pseudonovella paraconcinna (Manukalova et al., 1969). Less similar is Millerella_prilukiensis Vakarchuk in Brazhnikova et al., 1967, a species seemingly related to Pseudonovella as well as Millerella.

\section{Pseudonovella sp. 3}

Fig. 7 a-c

Sample: SA 11.

Measurements:

Specimen No.wh. $\mathrm{D}(0) \mathrm{D}(2) \mathrm{D}(3)$ D L/D W.th R.v. F.r. $\begin{array}{llllllllll}52(3) & 4-4.5 & 25 & 96 & 161 & 330 & 0.36 & 7 & 184 & 0.32\end{array}$

$\begin{array}{llllllllll}83(4) & 3.5 & 34 & 124 & 218 & 292 & 0.43 & 8 & 168 & 0.38\end{array}$

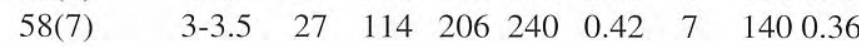

\section{Comparisons}

This small species may be assigned to the group of Pseudonovella carbonica (Grozdilova and Lebedeva, 1950) and is close to Pseudonovella paraconcinna (Manukalova et al., 1969). The latter species has more whorls and a larger diameter. Pseudonovella nataliae (Maslo, 1993) shows a similar shape but is a much larger species. Millerella grozdilovae (Maslo and Vachard, 1997) has a relatively large proloculum, a slightly larger diameter of the test, and less pronounced umbilical depressions. Millerella pseudostruvei var. losovskensis (Manukalova et al., 1969) shows a more rounded periphery.

\section{Pseudonovella sp. 4}

Fig. $7 \mathrm{~d}-\mathrm{h}$

Sample: SA 11.

\section{Measurements:}

Specimen No.wh.D(0) D(2) D(3) D L/D W.th R.v. F.r. $\begin{array}{llllllllll}33(2) & 5-5.5 & - & 92 & 159 & 560 & 0.37 & 12 & 322 & 0.32\end{array}$

2(1) $\quad \begin{array}{llllllllll}4.5-5 & 27 & 122 & 206 & 518 & 0.47 & 11 & 286 & 0.43\end{array}$

$\begin{array}{llllllllll}41(1) & 4.5-5 & 28 & 112 & 178 & 476 & 0.38 & 13 & 252 & 0.36\end{array}$

$\begin{array}{llllllllll}91(1) & 4.5 & 30 & 108 & 188 & 440 & 0.36 & 10 & 248 & 0.32\end{array}$

$\begin{array}{llllllllll}58(6) & 4.5 & 31 & 120 & 184 & 372 & 0.40 & - & 206 & 0.36\end{array}$

\section{Comparisons}

The somewhat similar Pseudonovella elegantula (Rauzer-Chernousova, 1951) shows more distinctly evolute initial whorls; its outer whorls are usually relatively lower and wider; quite similar is one of RauzerChernousova's paratypes (1951, pl. 2, fig. 8). Specimens identified as Millerella aff. elegantula (RauzerChernousova) in Manukalova et al. (1969, pl. XI, figs. 17-19) may be close too; these specimens and the Algerian specimens in comparison with the type specimen of Pseudonovella elegantula show outer whorls that are relatively higher, more acute, and more embracing. Pseudonovella nataliae (Maslo, 1993) is larger, has fewer and wider volutions, and shows conspicuous umbilical depressions.

\section{Pseudonovella sp. 5}

Fig. 7 i-1

Sample: SA 11. 

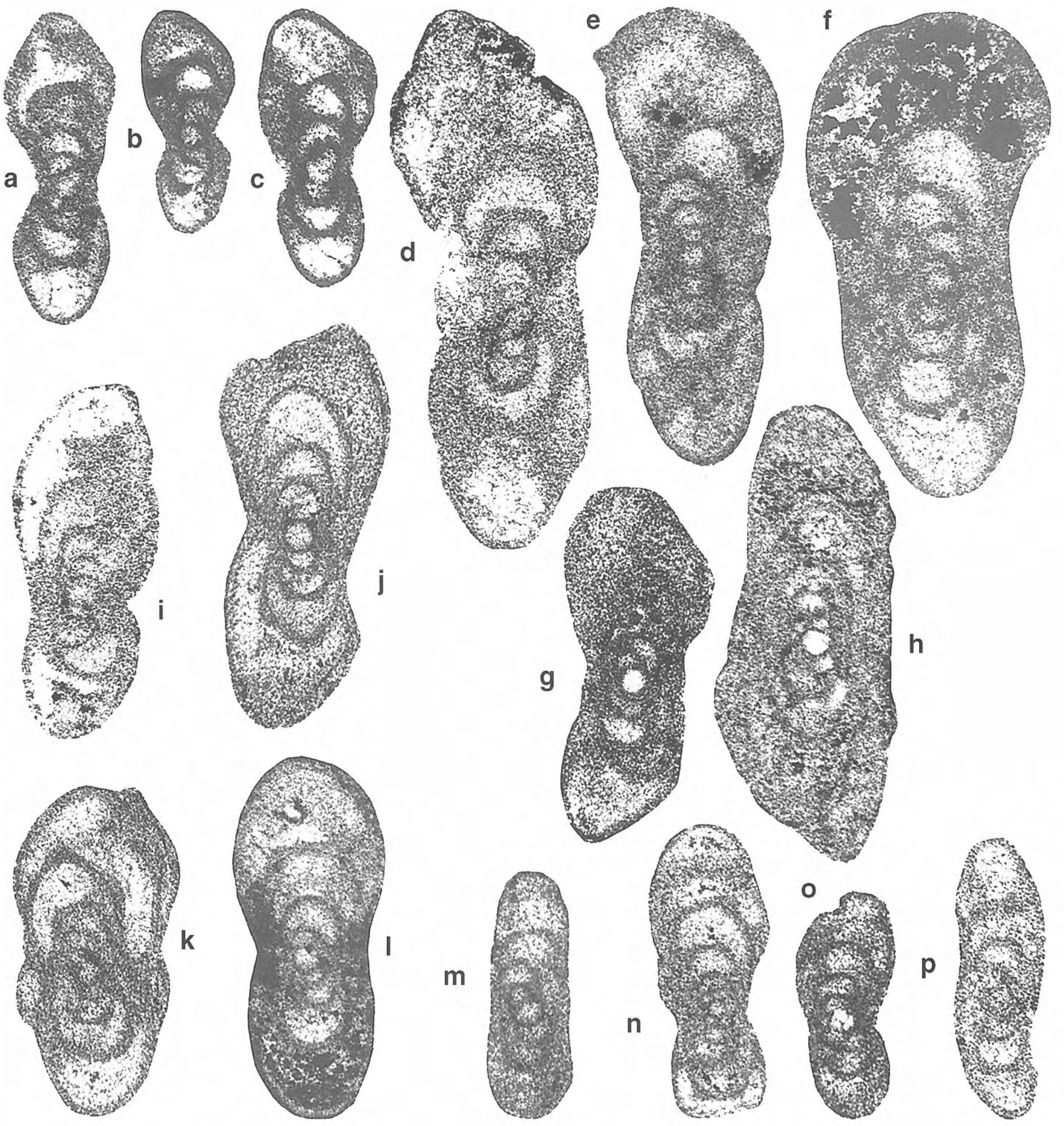

Figure 7.a-c. Pseudonovella sp. 3, specimens a. 11/52(3), b. 11/58(7), c. 11/83(4); d-h. Pseudonovella sp. 4, specimens d. 11/33(2), e. 11/41(1), f. 11/2(1), g. 11/58(6), h. 11/91(1); i-l. Pseudonovella sp. 5, specimens i. 11/23(1), j. 11/21(3), k. 11/69(1), 1. 11/9(1); m-p. Pseudonovella sp. 6, specimens m. 11/69(2), n. 11/69(3), o. 11/56(2), p. 11/33(5). Axial sections. All x160 (SA 11).

\section{Measurements:}

Specimen No.wh.D(0) D(2) D(3) D L/D W.th R.v. F.r. $\begin{array}{llllllllll}69(1) & 4.5 & 25 & 98 & 156 & 340 & 0.45 & 10 & 192 & 0.40\end{array}$

$\begin{array}{llllllllll}21(3) & 4.5 & 36 & 124 & 210 & 428 & 0.42 & 13 & 226 & 0.40\end{array}$ $\begin{array}{llllllllll}9(1) & 4 & 28 & 116 & 206 & 372 & 0.43 & 9 & 208 & 0.38\end{array}$ $\begin{array}{llllllllll}23(1) & 4 & 34 & 128 & 212 & 376 & 0.39 & 12 & 220 & 0.34\end{array}$

\section{Comparisons}

Pseudonovella sp. 5 is intermediate between Millerella of the pseudostruvei species group and Pseudonovella.

Millerella concinna Potievskaya, 1964 has deeper umbilical depressions, a smaller average diameter and 
fewer volutions. Millerella pseudostruvei (RauzerChernousova and Belyaev, 1936) shows inner volutions more clearly involute, and, on average, has a greater L/D ratio. Millerella (Seminovella) elegantula of Potievskaya (1964) has a smaller L/D ratio, more volutions, a smaller proloculum, and a larger maximum diameter. The adult stage of Potievskaya's specimens shows more distinct involution in comparison with typical Pseudonovella elegantula (Rauzer-Chernousova, 1951), and in this respect the Algerian specimens are obviously closer to Millerella (Seminovella) elegantula of Potievskaya (1964). Pseudonovella uralica is less similar; like typical Pseudonovella elegantula and unlike Pseudonovella sp. 5 , the holotype of this species shows clearly an evolute outer whorl.

\section{Pseudonovella sp. 6}

Fig. $7 \mathrm{~m}-\mathrm{p}$

Sample: SA 11.

\begin{tabular}{|c|c|c|c|c|c|c|c|c|}
\hline \multicolumn{9}{|c|}{ Measurements: } \\
\hline & & $\mathrm{D}(0)$ & $\mathrm{D}(2)$ & $\mathrm{D}(3)$ & D & $\mathrm{L} / \mathrm{D}$ & W.th & R.v. F.r. \\
\hline $69(3)$ & $4.5-5$ & 20 & 86 & 150 & 348 & 0.38 & 10 & 1960.34 \\
\hline 3365 & 4 & - & 112 & 184 & 300 & 0.32 & 7 & $\begin{array}{ll}176 & 0.27\end{array}$ \\
\hline $56(2)$ & 3.5 & 26 & 108 & 184 & 244 & 0.41 & 8 & $140 \quad 0.36$ \\
\hline $69(2)$ & 3.5 & 30 & 116 & 200 & 260 & 0.37 & 7 & $148 \quad 0.30$ \\
\hline
\end{tabular}

\section{Comparisons}

Like Pseudonovella sp 5, this small species also resembles Millerella of the Millerella pseudostruvei species group. Particularly similar are Pseudonovella variabilis (Rauzer-Chernousova, 1951), P. uralica (Kireeva, 1951), P. graciosa (Manukalova et al., 1969), and Millerella pseudostruvei var. losovskensis (Manukalova et al., 1969). The type specimen of Pseudonovella variabilis, in comparison with the Algerian specimens, shows relatively low and wide whorls. In this respect, the Algerian form is closer to Pseudonovella uralica and Pseudonovella graciosa. The two latter species have more whorls, and a smaller diameter at corresponding volutions. Millerella pseudostruvei var. losovskensis has a thicker wall, probably somewhat better developed secondary deposits, and larger maximum values for diameter of shell and proloculum.

\section{Remarks on the Pseudonovella species from the Tagnana Formation}

The Pseudonovella species from samples SA 11 and SA 13 resemble forms of the Pseudonovella carbonica and Pseudonovella elegantula species groups as well as some Millerella species (e. g. M. grozdilovae and $M$. ex gr. pseudostruvei). Therefore, some of them must be considered as transitional species. Wall structure and development of (discontinuous) chomata of the Algerian forms are essentially similar to these features in Millerella (see Moore, 1964 for a detailed description regarding the wall structure on the type species of

\begin{tabular}{lrrrrr}
\hline Wh.no. & 1 & 2 & 3 & 4 & 5 \\
\hline E & 42 & $\mathbf{5 6}$ & $\mathbf{5 6}$ & $\mathbf{4 7}$ & $\mathbf{5 6}$ \\
C & $\mathbf{5 8}$ & 44 & 44 & $\mathbf{4 7}$ & 33 \\
I & & & & 6 & 11 \\
\hline
\end{tabular}

Table 4. Development of evolute versus involute coiling in 18 specimens of Pseudonovella spp. (sp. 1-6). The three rows represent three classes expressing the amount of overlap between a whorl and its previous halfwhorl as can be observed in axial sections. The three classes of the table are E (= coiling evolute), $\mathrm{C}$ (= opposite half whorls just in contact at the poles) and I (= coiling involute). The table columns list for consecutive whorls the percentage of specimens of Pseudonovella spp. showing evolute, just-in-contact, or involute coiling. The number of observations per whorl may be as high as the number of specimens available (here eighteen) but is usually lower. The succession of heavy-type numbers (highest percentages in the columns) show the general development of the type of coiling.

Millerella). The main difference with respect to Millerella is apparently the way of coiling which in the Algerian forms is dominantly evolute in inner whorls (Table 4).

Millerella Thompson, 1942

Type species: Millerella marblensis Thompson, 1942.

\section{Millerella sp. 1 aff. M. paracarbonica Manukalova et al., 1969}

Fig. 5 d-i

Sample: SA 13.

\begin{tabular}{lccccccccc}
\multicolumn{7}{c}{ Measurements: } \\
No.wh. & $\mathrm{D}(0)$ & $\mathrm{D}(2)$ & $\mathrm{D}(3)$ & $\mathrm{D}$ & L/D & W.th. & R.v. & F.r. \\
$\mathrm{m}$ & 3.6 & 27 & 109 & 200 & 297 & 0.33 & 8 & 170 & 0.28 \\
$\mathrm{~s}$ & 0.4 & 2 & 12 & 26 & 61 & 0.05 & 1.1 & 36 & 0.05 \\
$\mathrm{n}=6$ & 4 & & & & & & & &
\end{tabular}

\section{Description}

Test small, slender discoidal; umbilical depressions shallow and wide. Periphery of the first whorl is flat or arched but tends to become more pointed with growth. The first one or two whorls are at a small or large angle to the subsequent two or three whorls; slight shifts may occur in the axis of coiling in outer whorls as well. The innermost two whorls of most specimens are evolute, whereas the outer two whorls are just in contact or slightly evolute. The wall of the outer whorls shows a tectum overlying a thicker more translucent layer. Secondary deposits are clearly present and form discontinuous chomata. 

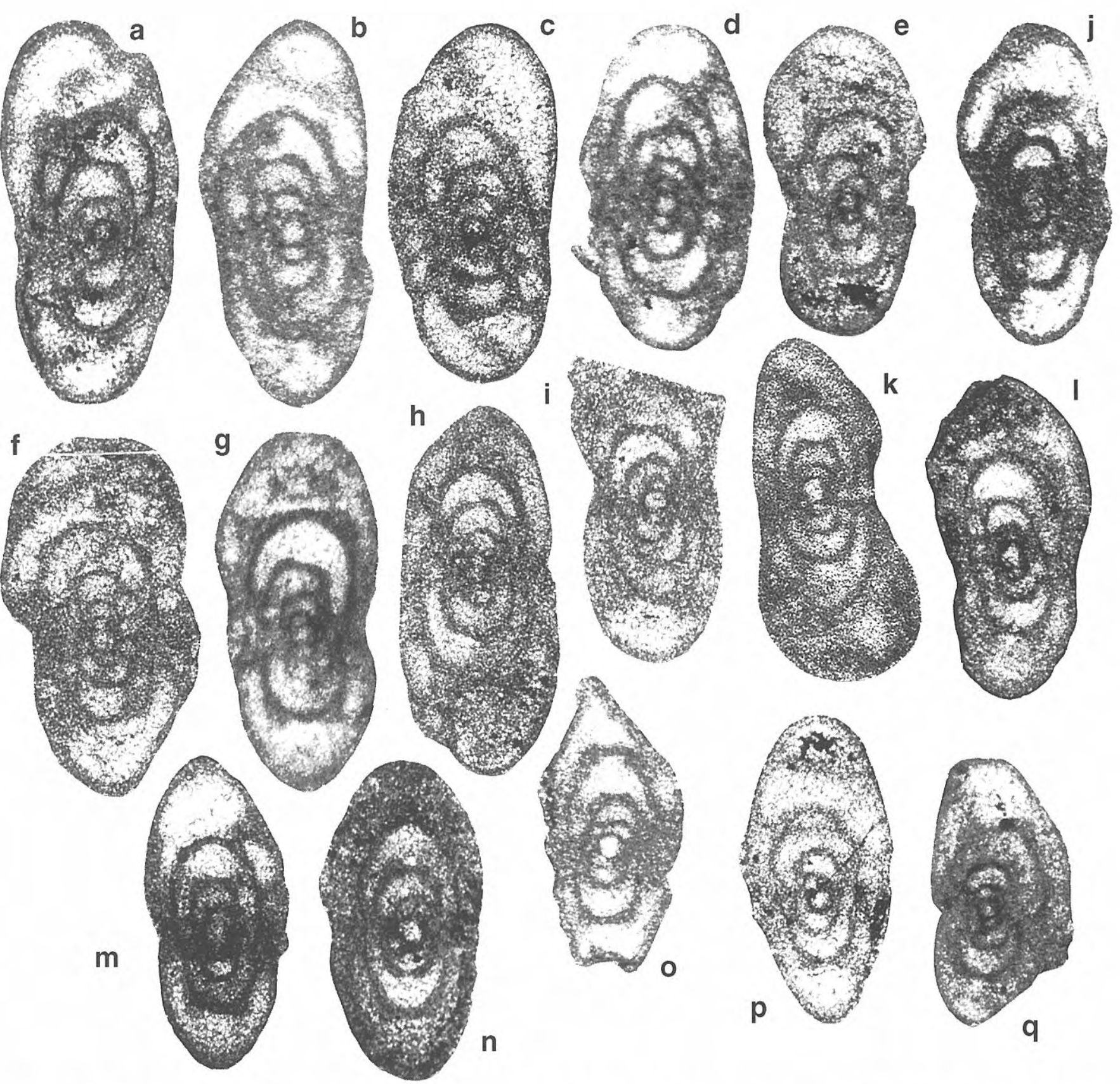

Figure 8. Millerella cf. pseudostruvei (Rauzer-Chernousova and Belyaev, 1936), specimens a. 11/39, b. 11/87(1), c. 11/99(2), d. 11/90(1), e. 11/17(5), f. 11/51(2), g. 11/17(2), h. 11/33(1), i. 11/48(3), j. 11/90(2), k. 11/26(1), l. 11/37(2), m. 11/69(4), n. 11/45(3), o. 11/18(1), p. 11/21(5), q. 11/68(1). Axial sections. All x160 (SA 11).

[Adjacent to the septa, chomata take the form of low to moderately high chomata, that show a low or steep slope at the tunnel side. Chomata and tunnel are not, or only weakly, present roughly half-way between consecutive septa. Here, the secondary deposits usually form merely a thickened cap of tectorium that may take the form of "a shoulder" in axial section. The tunnel and chomata are discontinuous apparently. Millerella marblensis Thompson, 1942 shows a similar morphology for tunnel and chomata (cf. Moore, 1964, p. 299)].

\section{Comparisons}

The present species is probably related to Millerella paracarbonica Manukalova, et al., 1969 and Millerella extensa Marshall, 1969. The most similar of the two, Millerella paracarbonica, differs by showing deeper umbilical depresssions, usually a more acute peripheral rim, a smaller proloculum, and a larger maximum number of whorls (up to five versus up to four in the Algerian species). The diameter of the fourth whorl of Millerella paracarbonica is smaller (220-300 versus 300-380 microns in the Algerian species) but the maximum shell diameter of Millerella paracarbonica is greater (420 versus 380 microns). The Algerian species resembles also Pseudonovella as well as species of the group of Millerella pseudostruvei [e.g. Millerella pseudostruvei 
var. losovskensis (Manukalova et al., 1969), M. amabilis (Grozdilova and Lebedeva, 1954)].

\section{Millerella sp. 2 aff. M. paracarbonica Manukalova et al., 1969}

Fig. 5 j-p

Sample: SA 13.

\section{Measurements:}

\begin{tabular}{|c|c|c|c|c|c|c|c|c|c|}
\hline & No.wh. & $\mathrm{D}(0)$ & $\mathrm{D}(2)$ & $\mathrm{D}(3)$ & D & L/D & W.th. & R.v. & F.r. \\
\hline $\mathrm{n}$ & 3.9 & 26 & 118 & 220 & 397 & 0.31 & 9 & 224 & 0.28 \\
\hline & 0.1 & 2.5 & 10 & 22 & 29 & 0.03 & 1.7 & 22 & 0. \\
\hline - & & 5 & 4 & 4 & & & & 5 & \\
\hline
\end{tabular}

\section{Comparisons}

This species is very similar to Millerella aff. paracarbonica (species 1) described above. The main difference between the two is the larger size of the present form. Also similar is Eostaffella acuta Grozdilova and Lebedeva, 1950, in Manukalova et al., 1969, (cf. specimens 19, 20, and 23, pl. VIII, p. 115).

\section{Millerella ex gr. acutissima (Kireeva, 1949)}

Fig. 6 a-s

Sample: SA 13.

\section{Measurements:}

$\begin{array}{lccccccccc} & \text { No.wh. } & \mathrm{D}(0) & \mathrm{D}(2) & \mathrm{D}(3) & \mathrm{D} & \text { L/D } & \text { W.th. } & \text { R.v. } & \text { F.r. } \\ \mathrm{m} & 4.2 & 25 & 112 & 206 & 427 & 0.33 & 9 & 246 & 0.28 \\ \mathrm{~s} & 0.3 & 3.5 & 14 & 26 & 75 & 0.04 & 1.3 & 47 & 0.04 \\ \mathrm{n}=19 & & 17 & & & & & & & \end{array}$

\section{Description}

The test develops from discoidal in innermost whorls, through nautiliform/lenticular in middle whorls, to lenticular/discoidal in outer whorls. Outer whorls generally show shallow and wide umbilical depressions; the inner one to three whorls have parallel sides and umbilical depressions are absent. The periphery of the shell up to the fourth whorl becomes gradually more pointed. Thereafter, the trend is reversed. Percentages of angularity of the periphery from the first to the fifth whorl are shown in Table 5. Coiling is either planispiral or, more commonly, the first 1-1.5 whorls are at a slight angle (usually not exceeding 30 degrees) to the subsequent whorls. As shown in Table 6, coiling is mainly evolute in whorls 1 and 5, and just in contact in whorls 2 to 4. Wall structure is often obscure, especially in inner whorls; Overlying a thicker and more translucent layer, the tectum in the outer whorls is usually seen. Chomata are higher near the septa and may not always be continuous between consecutive septa; they extend over the equatorial plane, where a wide and shallow depression, barely indicating a tunnel, is often observed.

\section{Comparisons}

In comparison with the present form, Millerella acutissima has fewer volutions and is smaller in size; its

\begin{tabular}{lrrrrr}
\hline Wh.no. & 1 & 2 & 3 & 4 & 5 \\
\hline S & 27 & 23 & 3 & & \\
A & $\mathbf{6 0}$ & $\mathbf{6 5}$ & 31 & 9 & $\mathbf{4 2}$ \\
A(blp) & & 12 & $\mathbf{3 7}$ & 18 & 29 \\
Blp & 13 & & 22 & $\mathbf{3 6}$ & 29 \\
P(blp) & & & 7 & 21 & \\
P & & & & 16 & \\
\hline
\end{tabular}

Table 5. Development of the degree of angularity of the peripheral rim in Millerella ex gr. acutissima. The six rows represent six classes of peripheral ranging from Straight/Flat (S) over Arched/Rounded (A), Bluntly pointed (Blp) to Pointed (P). The classes $\mathrm{A}(\mathrm{blp})$ and $\mathrm{P}(\mathrm{blp})$ are intermediate (cf. van Ginkel, 1965, p. 4). The table columns list for consecutive whorls (here: from 1 st to 5 th whorl) the percentages of specimens (of Millerella ex gr. acutissima in this case) of different degrees of peripheral angularity corresponding to one of the six classes. The number of observations per whorl may be as high as the number of specimens involved (in this case nineteen), but is usually lower. The succession of heavy-type numbers (highest percentages in consecutive columns) shows the general development of the periphery of the shell.

umbilical depressions are very shallow, and secondary deposits are hardly developed. Millerella paracarbonica Manukalova et al., 1969 has slightly more volutions, a smaller proloculum, a slightly smaller shell diameter, and a smaller length/diameter ratio. Millerella extensa Marshall, 1969 conforms in shape and size, but differs in that it has an uncoiled final growth stage. The Algerian specimen 13/15(1) (Fig. 6 g) compares closely with a specimen identified as Millerella marblensis by Hoare and Sturgeon (1994, OSU 47727, fig. 3-27). Some specimens suggest a relationship with species of the group of Millerella pseudostruvei such as specimen 13/66 (Fig. 6 r) which may be compared with Millerella angusta (Kireeva, 1951). The evolute innermost whorls of specimen 13/51 (Fig. 6 h) indicate a possible relationship with Pseudonovella. An interesting form is also specimen $13 / 24$ (Fig. 6 a), which would have certainly been assigned to Millerella levencovica (Manukalova et al., 1969), had it been an isolated specimen.

\begin{tabular}{lrrrrr}
\hline Wh.no. & 1 & 2 & 3 & 4 & 5 \\
\hline E & $\mathbf{7 5}$ & 26 & 15 & 35 & $\mathbf{7 5}$ \\
C & 25 & $\mathbf{6 7}$ & $\mathbf{7 0}$ & $\mathbf{5 0}$ & 10 \\
I & & 7 & 15 & 15 & 15 \\
\hline
\end{tabular}

Table 6. Development of evolute versus involute coiling in Millerella ex gr. acutissima (explanation as in Table 4). 

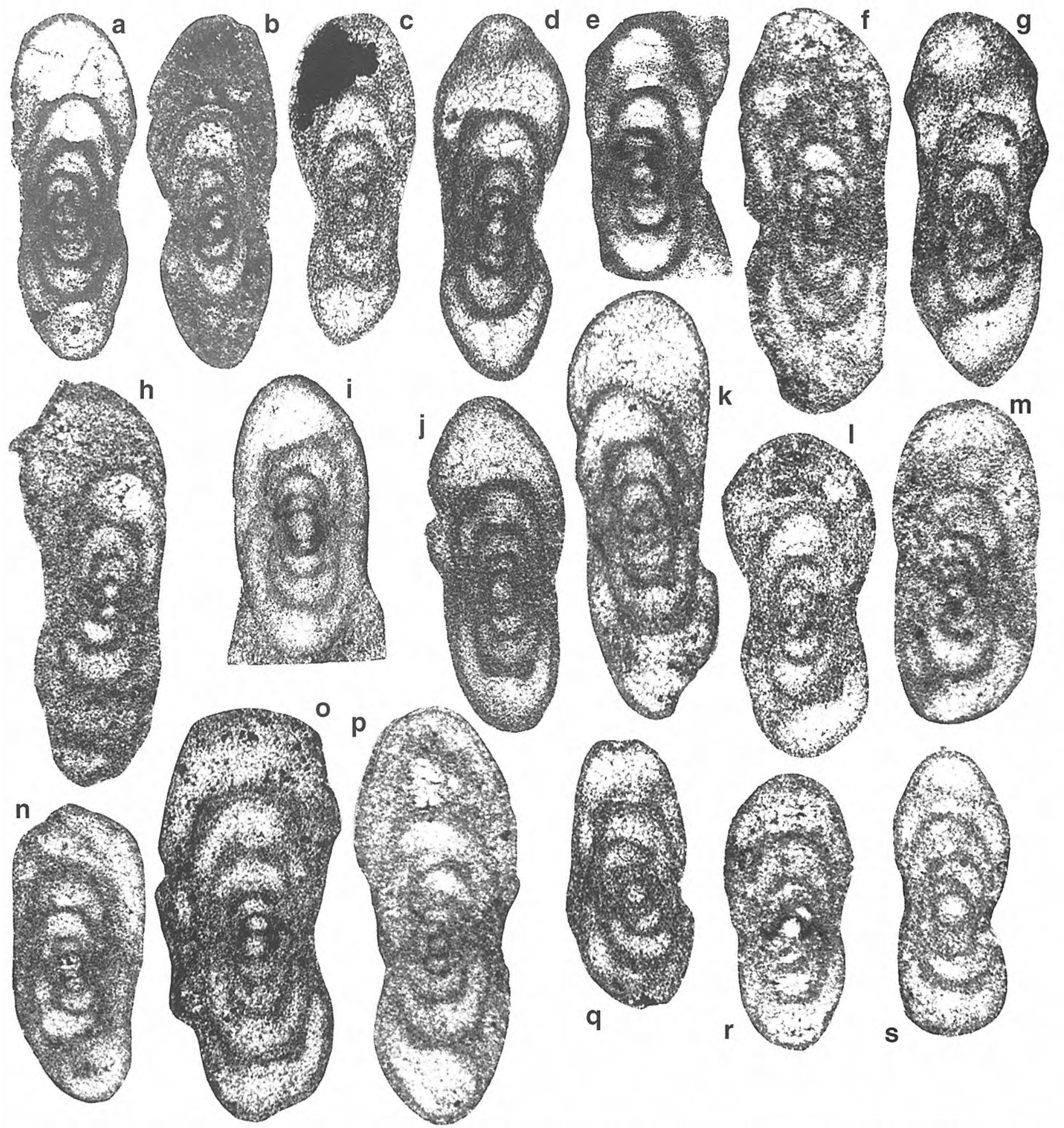

Figure 9. Millerella angusta (Kireeva, 1951), specimens a. 11/83(1), b. 11/1(1), c. 11/99(3), d. 11/64(2), e. 11/83(7), f. 11/44(4), g. 11/81(6), h. 11/78(2), i. 11/17(4), j. 11/56(1), k. 11/20(5), l. 11/21(9), m. 11/33(3), n. 11/33(4), o. 11/4(1), p. 11/29(2), q. 11/51(7), r. 11/20(6), s. 11/59(2). a-d. Form A; e-k. Form B; o,p. Form C; l-n, q-s. Form D. Axial sections. All x160 (SA 11).

\section{Remarks}

Millerella ex gr. acutissima contains small and slender species, showing an acute periphery, and partially evolute, occasionally involute coiling. The Eurasian species here considered to belong to this group are besides Millerella acutissima, also M. suixiensis
Wang, 1981, M. samarica Reitlinger, 1961, Eostaffella levencovica Manukalova et al., 1969, Millerella paracarbonica Manukalova et al., 1969, M. elevata Han and Zhao, 1984 (in Zhao et al.), and M. extensa Marshall, 1969 (see also Maslo and Vachard, 1997, p. $47,48)$. 


\begin{tabular}{lrrrrr}
\hline Wh.no. & 1 & 2 & 3 & 4 & 5 \\
\hline S & 23 & 29 & 16 & 2 & \\
A & $\mathbf{6 5}$ & $\mathbf{6 5}$ & $\mathbf{6 1}$ & 37 & 37 \\
A(blp) & 4 & 3 & 23 & $\mathbf{4 8}$ & $\mathbf{6 3}$ \\
Blp & 8 & 3 & & 10 & \\
P(blp) & & & & 3 & \\
P & & & & & \\
\hline
\end{tabular}

Table 7. Development of the degree of angularity of the peripheral rim in Millerella cf. pseudostruvei (explanation as in Table 5).

\section{Millerella cf. pseudostruvei}

(Rauzer-Chernousova and Belyaev, 1936) Fig. 8 a-q

Sample: SA 11.

\section{Measurements:}

$\begin{array}{lccccccccc} & \text { No.wh. } & \mathrm{D}(0) & \mathrm{D}(2) & \mathrm{D}(3) & \mathrm{D} & \text { L/D } & \text { W.th. } & \text { R.v. } & \text { F.r. } \\ \mathrm{m} & 4.15 & 27 & 111 & 192 & 363 & 0.49 & 9.5 & 207 & 0.43 \\ \mathrm{~s} & 0.4 & 2.5 & 16 & 28 & 54 & 0.03 & 1.5 & 30 & 0.04 \\ \mathrm{n}=17 & & 16 & & & & & 13 & & \end{array}$

\section{Description}

Test is nautiliform; umbilical cavities are absent or welldeveloped. Peripheral rim is mainly arched in whorls 1-3, and arched to bluntly pointed in whorls 4-5 (Table 7).

Coiling is planispiral, or inner one to two whorls are at a moderate angle to subsequent whorls. Volutions are evolute (first whorl), in contact (second whorl), involute (thirdfourth whorls), in contact or involute (fifth whorl) (Table 8).

The wall consists of a tectum overlying a thicker, less dense, layer from whorl 1.5 onwards, and occasionally is single-layered throughout growth. Chomata are discontinuous, low or (closer to the septa) of medium height.

\section{Comparisons}

The Algerian species is close to Millerella pseudostruvei; the number of volutions and the shell diameter of Millerella pseudostruvei average slightly greater. Also Eostaffella pseudostruvei of Bogush and Yuferev (1962, pl. VI, fig. 33) resembles several specimens of the present population. Millerella postmosquensis (Kireeva, 1951) has larger average values for proloculum and diameter at corresponding (inner)

\begin{tabular}{lrrrrr}
\hline Wh.no. & 1 & 2 & 3 & 4 & 5 \\
\hline E & $\mathbf{5 8}$ & 24 & 6 & & \\
C & 42 & $\mathbf{4 7}$ & 44 & 24 & $\mathbf{6 4}$ \\
I & & 29 & $\mathbf{5 0}$ & $\mathbf{7 6}$ & 36 \\
\hline
\end{tabular}

Table 8. Development of evolute versus involute coiling in Millerella cf. pseudostruvei (explanation as in Table 4).

\begin{tabular}{lrrrrr}
\hline Wh.no. & 1 & 2 & 3 & 4 & 5 \\
\hline S & 18 & 22 & 21 & 3 & \\
A & $\mathbf{7 9}$ & $\mathbf{7 2}$ & $\mathbf{5 3}$ & $\mathbf{4 2}$ & 29 \\
A(blp) & & & 23 & 29 & $\mathbf{4 2}$ \\
Blp & 3 & 6 & 3 & 26 & 29 \\
P(blp) & & & & & \\
P & & & & & \\
\hline
\end{tabular}

Table 9. Development of the degree of angularity of the peripheral rim in Millerella angusta (explanation as in Table 5).

volutions. Millerella cumberlandensis (Rich, 1980), unlike some Algerian specimens, hardly shows umbilical depressions.

\section{Millerella angusta \\ (Kireeva, 1951) \\ Fig. 9 a-s}

Sample: SA 11.

\section{Measurements:}

No.wh. $\mathrm{D}(0) \mathrm{D}(2) \mathrm{D}(3)$ D L/D W.th. R.v. F.r.

$\begin{array}{lccccccccc}\mathrm{m} & 4.1 & 27.5 & 114 & 200 & 363 & 0.42 & 9 & 209 & 0.37 \\ \mathrm{~s} & 0.4 & 5 & 18 & 30 & 66 & 0.05 & 2 & 39 & 0.05 \\ \mathrm{n}=22 & & 21 & & & & & & & \end{array}$

Form Fig. No.wh. D(0) D(2) D(3) D L/D W.th. R.v. F.r. $\begin{array}{lllllllllll}\text { A } & \text { A-D } & 4.4 & 23 & 93 & 168 & 378 & 0.36 & 8 & 220 & 0.31\end{array}$ $\begin{array}{lllllllllll}\text { B } & \text { E-K } & 4.1 & 27 & 114 & 197 & 373 & 0.41 & 9 & 212 & 0.36\end{array}$ $\begin{array}{lllllllllll}\text { C } & \text { O-P } & 4.4 & 27 & 128 & 223 & 474 & 0.41 & 13 & 288 & 0.35\end{array}$

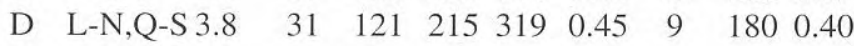

\section{Description}

Test is discoidal to nautiliform; umbilical depressions are often absent in the inner three whorls and shallow to deep in the outer whorls. Peripheral rim is predominantly arched in whorls 1-4 and usually arched to bluntly pointed in whorl 5 (Table 9).

Specimens show small shifts of the axis of coiling, notably in inner whorls. Coiling is evolute or in contact (first whorl), in contact (second-fourth whorls), and evolute (fifth whorl) (Table 10).

Except for the initial one or two whorls which are singlelayered, the spirotheca shows a tectum overlying a thicker,

\begin{tabular}{lrrrrr}
\hline Wh.no. & 1 & 2 & 3 & 4 & 5 \\
\hline E & $\mathbf{5 0}$ & 30 & 5 & 32 & $\mathbf{7 0}$ \\
C & $\mathbf{5 0}$ & $\mathbf{4 0}$ & $\mathbf{6 0}$ & $\mathbf{3 6}$ & 30 \\
I & & 30 & 35 & 32 & \\
\hline
\end{tabular}

Table 10. Development of evolute versus involute coiling in Millerella angusta (explanation as in Table 4). 

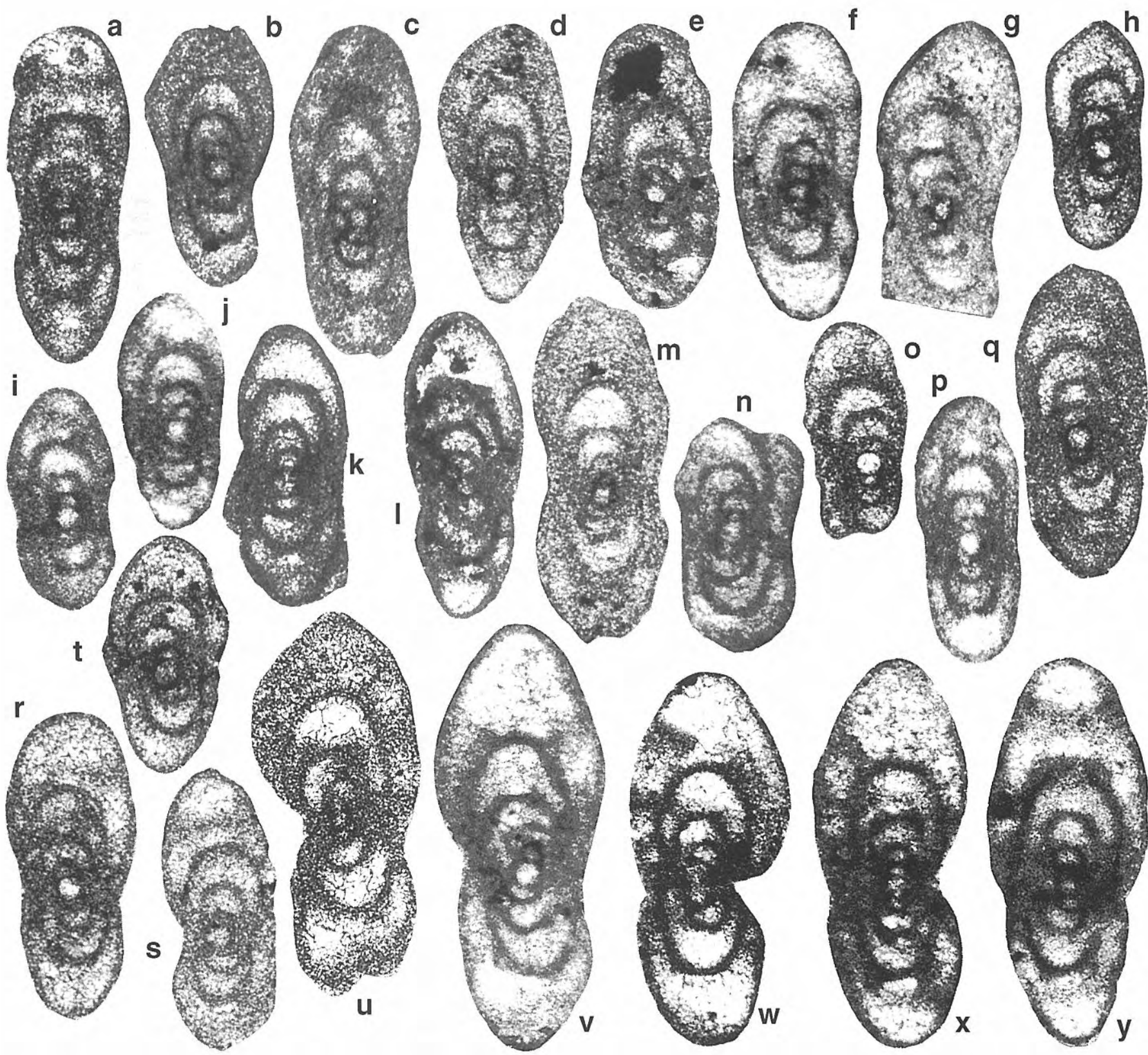

h

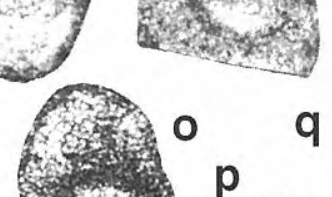

$\mathrm{m}$

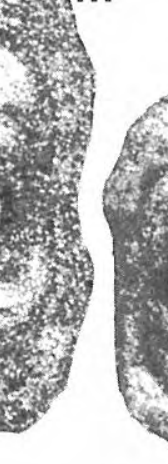

n
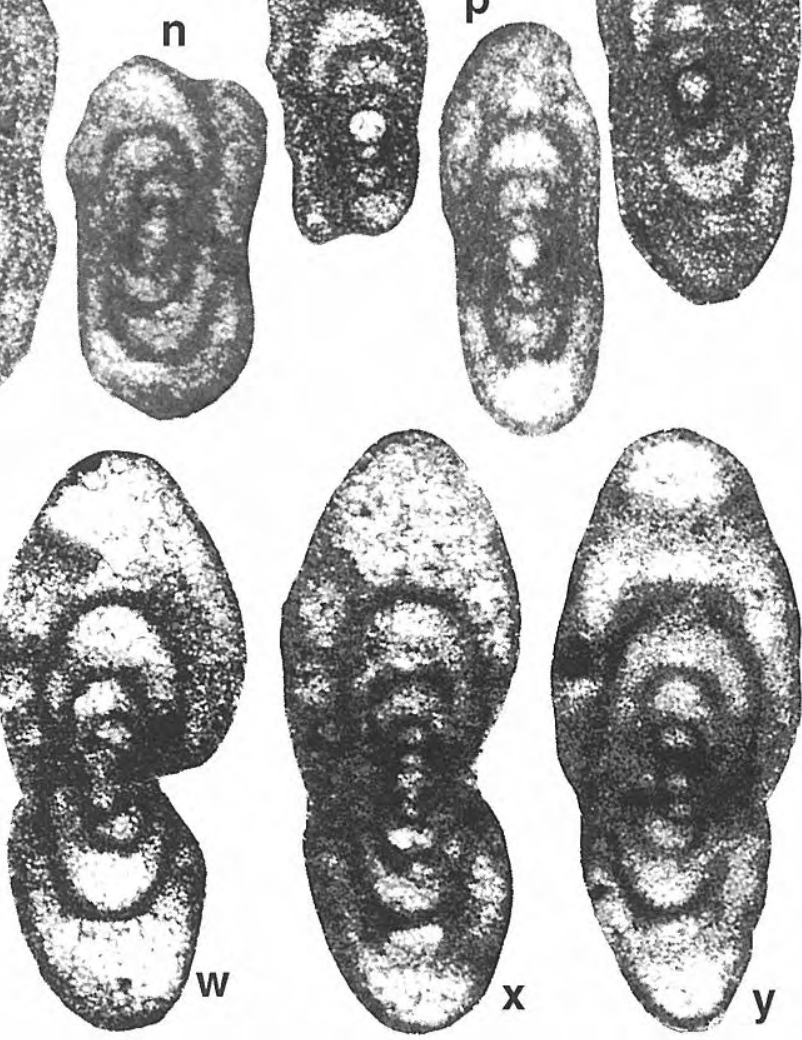

Figure 10. a-t. Millerella jugorskensis (Solovieva, 1984), specimens a. 11/37(1), b. 11/67, c. 11/16(2), d. 11/24(5), e. 11/42(3), f. 11/26(3), g. 11/5(5), h. 11/20(3), i. 11/26(4), j. 11/22(3), k. 11/81(2), l. 11/58(1), m. 11/41(6), n. 11/79(1), o. 11/23(4), p. 11/78(1), q. 11/44(6), r. 11/34(2), s. 11/44(5), t. 11/63(5); u-y. Millerella sp.1 ex gr. M. pseudostruvei (Rauzer-Chernousova and Belyaev, 1936), specimens u. 11/66(2), v. 11/84, w. 11/7(3), x. 11/76, y. 11/17(3). Axial sections. All x160 (SA 11).

less dense, layer. Occasionally, the spirotheca is singlelayered throughout growth. Secondary deposits may be observed from whorl 1.5-2 onwards. Chomata are discontinuous, rather wide, low or moderately high, showing low or steep slopes at the tunnel side. About halfway between septa, secondary deposits form "shoulders", and chomata and tunnel can hardly be distinguished as such.

The present material is quite variable. Several types (forms A to D) have been distinguished. Form B is intermediate with respect to the forms $\mathrm{A}$ and $\mathrm{C}$. Form $\mathrm{A}$ is small, showing clearly evolute outer whorls and a subacute peripheral rim, whereas the larger Form $\mathrm{C}$ has better developed chomata. Form D includes specimens showing slightly fewer volutions and a slightly larger proloculum.

\section{Comparisons}

The present specimens are considered to belong to the species Millerella angusta, despite the slightly smaller proloculum, the smaller diameter per volution (from first to third whorl), the larger average L/D ratio, and the better developed chomata (form C) of the Algerian specimens. The Algerian specimens are intermediate in size between those from the Donets Basin described by Manukalova et al. (1969) and the much larger typical forms from the 


\begin{tabular}{lrrrr}
\hline Wh.no. & 1 & 2 & 3 & 4 \\
\hline S & 15 & 19 & & 8 \\
A & $\mathbf{8 5}$ & $\mathbf{7 5}$ & $\mathbf{7 5}$ & 25 \\
A(blp) & & 6 & 25 & $\mathbf{6 7}$ \\
Blp & & & & \\
P(blp) & & & & \\
P & & & & \\
\hline
\end{tabular}

Table 11. Development of the degree of angularity of the peripheral rim in Millerella yugorskensis (explanation as in Table 5).

Urals. Very similar is Millerella sp. (Groves, 1984, pl. 7, figs. 7-12); the illustrations suggest that the main difference is the number of whorls, being up to five for Millerella sp. and up to four and one half for the Algerian species. The form identified as Eostaffella pseudostruvei var. elegantissima (in: Manukalova et al., 1969, p.189, pl. IX, fig. 16; p.7, pl. XIII, fig. 13) differs from the Algerian species by its better developed chomata, slightly thicker spirotheca, slightly greater number of whorls, and slightly smaller proloculum; it is very similar to the specimens here distinguished as Form C. Another related species may be Millerella porcupinensis Ross, 1967, which resembles in wall structure, development of chomata, and shell shape. It attains however, a much larger diameter (up to 700 microns).

\section{Millerella yugorskensis (Solovieva, 1984)} Fig. 10 a- $t$

\section{Sample: SA 11.}

\section{Measurements:}

$\begin{array}{lccccccccc} & \text { No.wh. } & \mathrm{D}(0) & \mathrm{D}(2) & \mathrm{D}(3) & \mathrm{D} & \text { L/D } & \text { W.th. } & \text { R.v. } & \text { F.r. } \\ \mathrm{m} & 3.75 & 24.5 & 103 & 183 & 290 & 0.45 & 8 & 163 & 0.39 \\ \mathrm{~s} & 0.25 & 2.6 & 9 & 21 & 39 & 0.05 & 0.9 & 22 & 0.04 \\ \mathrm{n}=23 & & 22 & & & 22 & 22 & 20 & & \end{array}$

\section{Description}

Test is small, discoidal or plano-nautiliform. Umbilical depressions are absent or (rarely) moderately deep. Periphery develops from arched (first-third whorl), towards arched to bluntly pointed (fourth whorl). Percentages of angularity for whorls 1-4 are shown in Table 11.

Specimens show skew coiling in the two first whorls or (occasionally) throughout growth; others are planispiral. Volutions are predominantly evolute (first-second whorl), in contact (second-third whorl), or involute (fourth whorl) (Table 12).

A tectum can be distinguished in some or all volutions except the innermost one; occasionally the tectum appears to be absent throughout growth. These differences are probably caused by differences in preservation. Secondary deposits (in the form of discontinuous chomata) appear in the secondthird whorl and are low or moderately high and relatively wide.

\begin{tabular}{lrrrr}
\hline Wh.no. & 1 & 2 & 3 & 4 \\
\hline E & $\mathbf{6 8}$ & $\mathbf{4 4}$ & 12 & 12 \\
C & 32 & $\mathbf{4 4}$ & $\mathbf{5 0}$ & 38 \\
I & & 12 & 38 & $\mathbf{5 0}$ \\
\hline
\end{tabular}

Table 12. Development of evolute versus involute coiling in Millerella yugorskensis (explanation as in Table 4).

\section{Comparisons}

The species is a small member of the Millerella pseudostruvei species group. The specimens described by Solovieva show a slightly larger diameter. Other related but less similar forms are Millerella pseudostruvei forma minima (Kireeva, 1949) (cf. Manukalova et al., 1969, pl. VI, figs. 5-8) and Millerella amabilis (Grozdilova and Lebedeva, 1954). The present specimens usually show a slightly evolute first whorl. This partially evolute coiling of the first one or two whorls points to a relationship with Pseudonovella.

\section{Millerella sp. 1 ex gr. M. pseudostruvei (Rauzer-Chernousova and Belyaev, 1936) Fig. $10 \mathrm{u}-\mathrm{y}$}

Sample: SA 11.

\begin{tabular}{lccccccccc}
\multicolumn{2}{c}{ Measurements: } \\
\multicolumn{1}{c}{ No.wh. } & $\mathrm{D}(0)$ & $\mathrm{D}(2)$ & $\mathrm{D}(3)$ & $\mathrm{D}$ & $\mathrm{L} / \mathrm{D}$ & W.th. & R.v. & F.r. \\
$\mathrm{m}$ & 4.35 & 23 & 99 & 174 & 382 & 0.43 & 9 & 220 & 0.37 \\
$\mathrm{~s}$ & 0.15 & 3.5 & 7 & 12 & 24 & 0.03 & 1 & 19 & 0.03 \\
$\mathrm{n}=5$ & & 4 & & & & & & &
\end{tabular}

\section{Description}

Shell shape changes from nautiliform (first-third whorls) to discoidal (fourth-fifth whorls); the last whorl usually shows conspicuous umbilical cavities. The periphery is predominantly arched or flat (first-second whorls), arched (third whorl) and arched to bluntly pointed (fourth whorl). Axis of coiling is not stable throughout growth but shifts are minimal; the first whorl, commonly, is at a slight angle to subsequent whorls. Volutions are predominantly evolute in the first two whorls and mainly in contact in the following whorls. The wall shows a tectum overlying a thicker more translucent layer. Secondary deposits are quite variable, occasionally absent. Adjacent to the septa, low or moderately high and relatively wide chomata can usually be observed.

\section{Comparisons}

Millerella pseudostruvei shows a slightly wider arched peripheral rim in outer whorls, and possibly shallower umbilical depressions. Millerella bigemmicula Igo, 1957 has slightly fewer volutions and a larger proloculum. The diameter of the fourth whorl is slightly greater and the spirotheca is slightly thicker. Secondary deposits may be better developed. Less similar is 

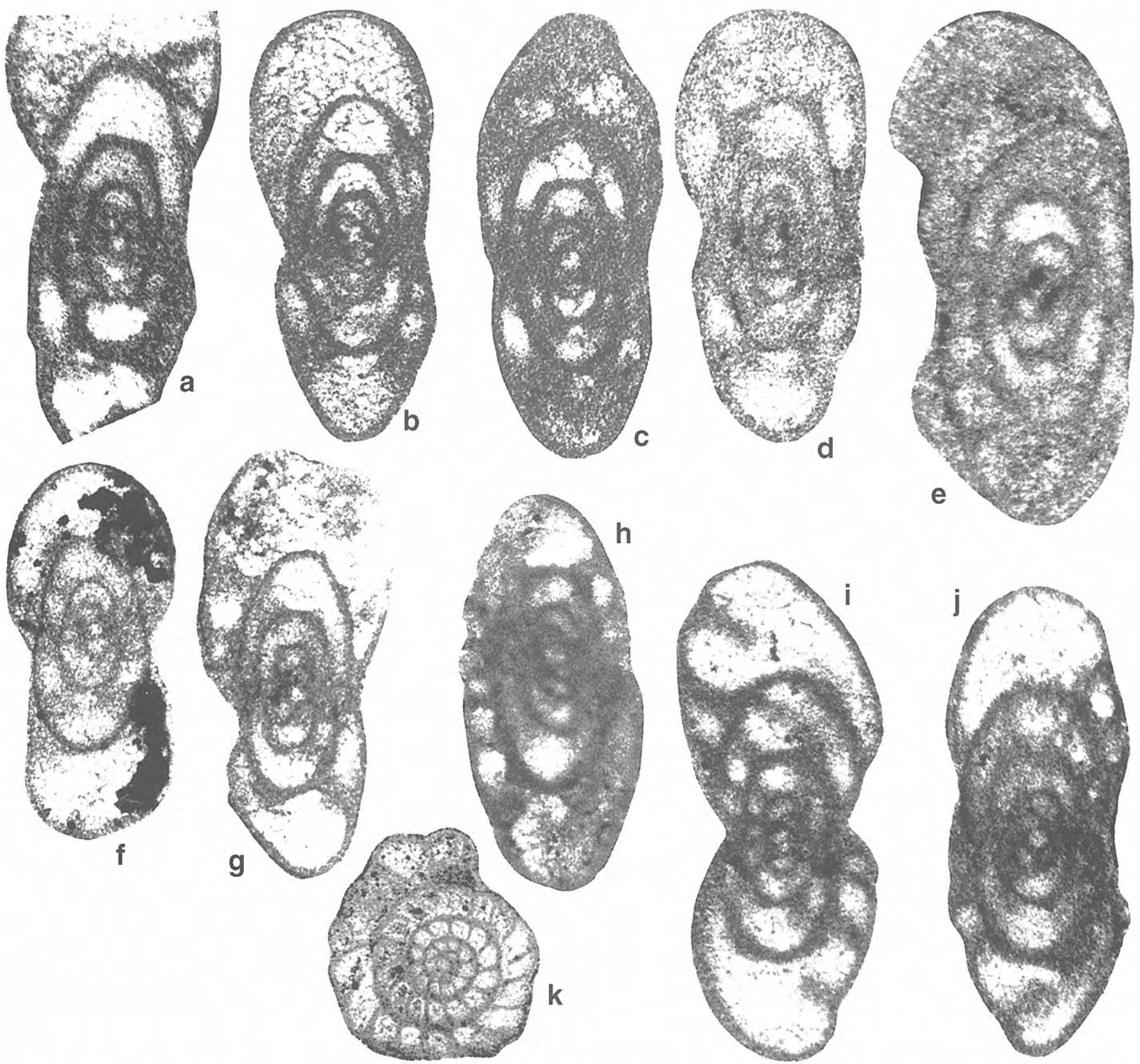

Figure 11. a-g. Millerella sp. 2 ex gr. M. pseudostruvei (Rauzer-Chernousova and Belyaev, 1936), specimens a. 11/88(2), b. 11/70, c. 11/81(3), d. 11/34(6), e. 11/34(1), f. 11/50(1), g. 11/6(9); h-j. Millerella sp. 3 ex gr. M. pseudostruvei (Rauzer-Chernousova and Belyaev, 1936), specimens h. 11/74(1), i. 11/58(2), j. 11/65(3); k. Millerella or Eostaffella, specimen 79(3). a-g, h-j. axial sections (all x160); k. sagittal section (x70). All SA 11.

Millerella postmosquensis acutiformis (Kireeva, 1951) which shows fewer volutions, a larger proloculum, a larger diameter at corresponding volutions, a greater L/D ratio, and probably shallower umbilical depressions. Closely related is the species described below as Millerella ex gr. pseudostruvei sp. 2.

\section{Remarks}

Rauzer-Chernousova et al. (1951) introduced the species group of Eostaffella pseudostruvei. Despite the poor information on the leader of the group (the introduction in 1936 of Staffella pseudostruvei includes only one illustrated specimen) the following species are believed to be possible members:

Eostaffella alongensis Saurin, 1967, E. amabilis Grozdilova and Lebedeva, 1954, E. etoi Ota, 1971, E. evolutica Rumyantseva, 1970, E. excavata Niko, 1987, E. instabilis Ektova, 1976, E. (E.) pseudostruvei angusta Kireeva, 1951, E. pseudostruvei yugorskensis Solovieva, 1984, E. (Millerella) umbilicata Kireeva, 1951, Millerella bigemmicula Igo, 1957, M. concinna Potievskaya, 1964, M. komatui Igo, 1957.

Eostaffella postmosquensis Kireeva, 1951, E. akiyoshiensis Sada, 1975, and E. cumberlandensis Rich, 


\begin{tabular}{lrrrrr}
\hline Wh.no. & 1 & 2 & 3 & 4 & 5 \\
\hline S & 9 & 8 & 7 & & \\
A & $\mathbf{9 1}$ & $\mathbf{9 2}$ & $\mathbf{5 8}$ & 21 & $\mathbf{6 2}$ \\
A(blp) & & & 21 & 36 & 13 \\
Blp & & & 14 & $\mathbf{4 3}$ & 25 \\
P(blp) & & & & & \\
P & & & & & \\
\hline
\end{tabular}

Table 13. Development of the degree of angularity of the peripheral rim in Millerella sp. 2 ex gr. pseudostruvei (explanation as in Table 5).

1980 should perhaps be added here too. Yet RauzerChernousova et al. (1951) assigned E. postmosquensis not to the species group of E. pseudostruvei but to the more primitive species group of E. parva (Möller, 1879). Subsequently, Eostaffella parva was designated as the type species of Endostaffella by Rozovskaya (1961). This suggests that Eostaffella postmosquensis and the other two similar species may have derived from Endostaffella. The pseudostruvei species group probably descended from Endostaffella as well.

\section{Millerella sp. 2 ex gr. M. pseudostruvei (Rauzer-Chernousova and Belyaev, 1936)} Fig. $11 \mathrm{a}-\mathrm{g}$

\section{Locality: SA 11.}

\section{Measurements:}

$\begin{array}{lccccccccc} & \text { No.wh. } & \mathrm{D}(0) & \mathrm{D}(2) & \mathrm{D}(3) & \mathrm{D} & \text { L/D } & \text { W.th. } & \text { R.v. } & \text { F.r. } \\ \mathrm{m} & 4.45 & 21 & 99 & 186 & 434 & 0.44 & 10.5 & 239 & 0.39 \\ \mathrm{~s} & 0.3 & 3 & 9 & 23 & 61 & 0.02 & 1 & 31 & 0.03 \\ \mathrm{n}=7 & & 5 & 6 & & & & & & \end{array}$

\section{Description}

Inner volutions are nautiliform or lenticular; outer whorls discoidal. The umbilical region in the inner whorls is usually flat, occasionally slightly umbonate; the outer volutions show shallow or deep umbilical depressions. The periphery is usually arched in the inner three and fifth volutions; the fourth volution shows a more pointed periphery (Table 13).

Coiling is planispiral, except for the first 0.5-1.5 whorls, which usually are at an angle to subsequent whorls. Slight axial shifts may occur throughout growth. Volutions are usually in contact in whorls 1-2, mainly involute in whorls $2-4$, and mainly in contact or evolute in whorl 5 (Table 14).

The wall consists of a tectum overlying a thicker and more translucent layer; secondary deposits are present from whorls 1.5-2.5 and take the form of low or moderately high and relatively wide, discontinuous, chomata which have fairly steep slopes at the side of the tunnel (up to 90 degrees near the tunnel openings).

\section{Comparisons}

Millerella pseudostruvei (Rauzer-Chernousova and Belyaev, 1936) probably has a smaller average diameter;

\begin{tabular}{lrrrrr}
\hline Wh.no. & 1 & 2 & 3 & 4 & 5 \\
\hline E & 25 & 16 & & 16 & $\mathbf{4 2}$ \\
C & $\mathbf{6 2}$ & $\mathbf{4 2}$ & 7 & 16 & $\mathbf{4 2}$ \\
I & 13 & $\mathbf{4 2}$ & $\mathbf{9 3}$ & $\mathbf{6 8}$ & 16 \\
\hline
\end{tabular}

Table 14. Development of evolute versus involute coiling in Millerella sp. 2 ex gr. pseudostruvei (explanation as in Table 4).

evolute specimens as shown in the present material are apparently absent. Millerella angusta and Millerella porcupinensis Ross, 1967 have fewer whorls, a larger proloculum, and a larger diameter at corresponding whorls. Eostaffella ex gr. mixta of Manukalova et al. (1969, p.34, pl. X) is a more slender form (L/D ratio= $0.34-0.36$ versus $0.40-0.47$ ) and may have better developed secondary deposits. Similar are also the older Millerella orbiculata (Maslo, 1993) and Millerella designata Zeller, 1953. Both show umbilicate and slender inner whorls in contact at the poles, whereas the corresponding whorls of the Algerian specimens are rather nautiliform and involute.

\section{Millerella sp. 3 ex gr. M. pseudostruvei (Rauzer-Chernousova and Belyaev, 1936) Fig. $11 \mathrm{~h}-\mathrm{j}$}

Sample: SA 11.

Measurements:

Specimen No.wh.D(0) D(2) D(3) D L/D W.th. R.v. F.r. $\begin{array}{llllllllll}65(3) & 4.5 & 24 & 108 & 204 & 452 & 0.38 & 11 & 244 & 0.35\end{array}$ $\begin{array}{llllllllll}74(1) & 4-4.5 & 23 & 108 & 182 & 392 & 0.44 & 10 & 232 & 0.37\end{array}$ $\begin{array}{llllllllll}58(2) & 4.5 & 23 & 102 & 194 & 484 & 0.40 & 10 & 272 & 0.35\end{array}$

\section{Description}

Specimens are discoidal and have flat or clearly depressed umbilical areas. The periphery changes from flat (first whorl), arched (second-third whorls), arched to bluntly pointed (fourth whorl) to arched (fifth whorl). The initial whorl is at an angle to the second whorl; the axis of coiling is not fully stable in succeeding whorls. Coiling is evolute or in contact (first whorl), in contact or involute (third-fourth whorls), and again evolute (fifth whorl). Chomata are discontinuous, and usually fairly high adjacent to the septa. The wall consists of tectum and a thicker, more translucent, lower layer.

\section{Comparisons}

The present species resembles Millerella sp. 2 ex gr. M. pseudostruvei described above, but differs in the slight angular shifts of the axis of coiling during growth, whereas Millerella sp. 2 is planispiral. There could be a relationship with Plectostaffella longiscula Rumyantseva and Orlova in Kulagina et al. (1992) which species probably belongs to the Plectostaffella varvariensis species group. However, the Algerian specimens are considered closer to Millerella than to Plectostaffella. 


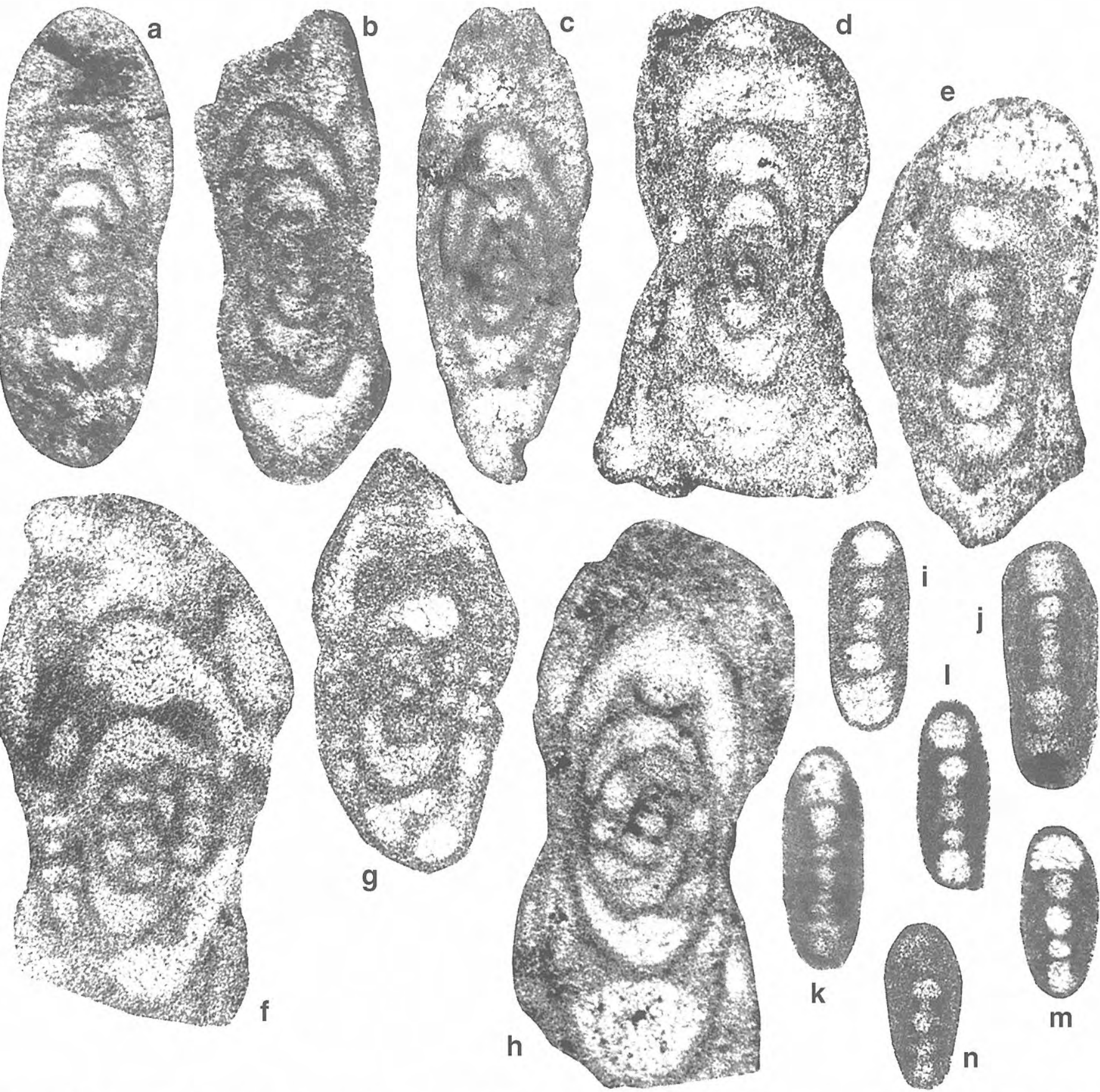

Figure 12. a-c. Millerella ex gr. chomatifera (Kireeva, 1951), specimens a. 11/9(3), b. 11/24(4), c. 13/20(1); d,e. Millerella cf, paraumbilicata Manukalova et al.,1969, specimens d. 11/44(1), e. 11/78(3); f-h. Millerella aff. paraumbilicata Manukalova et al.,1969, specimens f. 11/49(1), g. 11/62(2), h. 11/24(2); i-n. Mediocris breviscula (Ganelina, 1951), specimens i. 11/62(4), j. 11/9(4), k. 11/46(5), l. 11/77(2) m. 11/91(6), n. 11/31(5). Axial sections. All x160 (SA 11; specimen c: SA 13).

Millerella ex gr. chomatifera (Kireeva, 1951)

Fig. 12 a-c

Sample: SA 11 and SA 13.

\section{Measurements:}

Specimen No.wh.D(0) D(2) D(3) D L/D W.th. R.v. F.r. (SA 11)

24(4)

4.5

$\begin{array}{llllllllll}9(3) & 4.5 & 26 & 108 & 208 & 450 & 0.37 & 12 & 248 & 0.34 \\ 1(2) & 5.5 & 22 & 104 & 180 & 528 & 0.36 & 12 & 300 & 0.31 \\ \text { (SA 13) } & & & & & & & & & \\ 20(1) & 4-4.5 & 27 & 120 & 224 & 480 & 0.35 & 10 & 284 & 0.30 \\ 42(1) & 4-4.5 & 19 & 105 & 195 & 416 & 0.45 & 9.5 & 264 & 0.38 \\ 20(2) & 3.5-4 & 32 & 140 & 278 & 432 & 0.42 & 9 & 240 & 0.37\end{array}$

\section{Description}

Test lenticular, discoidal, or nautiliform. Axial region flat or slightly raised; umbilical depressions absent or 
shallow. Lateral sides straight or convex. Peripheral rim of inner whorls flat or arched, and bluntly pointed or subacute in outer whorls. Axis of coiling in the first one or two whorls may be at a (small) angle to later whorls. First whorl can be evolute, subsequent whorls are in contact at the poles or involute, and the final whorl is sometimes evolute. Spirotheca shows tectum and a thicker, more translucent, lower layer. The chomata are of medium height and width.

\section{Comparisons}

Specimens resemble Millerella chomatifera (Kireeva, 1951) (= Eostaffella pseudostruvei chomatifera Kireeva, 1951), Millerella pseudostruvei var. elegantissima (Manukalova et al., 1969), and Millerella etoi (Ota, 1971). Possibly conspecific is Millerella pseudostruvei var. elegantissima. However, the "variety" is not a valid category in zoological nomenclature since 1960 (ICZN, 1999, Art. 45,5; 45,6.3). Millerella chomatifera differs in shape: plano-nautiliform in Millerella chomatifera and more slender, lenticular, in the Algerian specimens. Millerella etoi has slightly fewer whorls, a larger proloculum, a larger diameter at corresponding whorls, and probably less developed chomata. Somewhat similar is also Eostaffella postmosquensis acutiformis of Groves (1991).

\section{Remarks}

Species closely related to Millerella pseudostruvei but showing better developed chomata are included in the species group Millerella chomatifera. In addition to Eostaffella chomatifera Kireeva, 1951, the present report includes the following species: Eostaffella citata Bogush and Yuferev, 1962, E. designata chaoxianensis Wang, 1981, E. endothyroidea Chang, 1962, E. fenghuangshanensis, Wang, 1981, E. klautzanae Grozdilova and Lebedeva, 1960, E. mixta Rauzer-Chernousova, 1951, E. paraendothyroidea Rich, Millerella inflecta Thompson, 1945, M. paraumbilicata Manukalova et al., 1969, M. pinguis Thompson, 1994, and M. porcupinensis Ross, 1967. (See also Maslo and Vachard, 1997, p. 44).

\section{Millerella cf. paraumbilicata Manukalova et al., 1969}

Fig. 12 d,e

Sample: SA 11.

\section{Measurements:}

Specimen No.wh.D(0) D(2) D(3) D L/D W.th. R.v. F.r. $\begin{array}{llllllllll}44(1) & 4.5(5) & 27 & 108 & 200 & 472 & 0.40 & 11 & 276 & 0.34\end{array}$

$\begin{array}{llllllllll}78(3) & 4.5 & 34 & 120 & 212 & 432 & 0.51 & 14 & 248 & 0.44\end{array}$

\section{Comparisons}

Similar is Millerella paraumbilicata Manukalova et al., 1969 (cf. fig. 24, pl. XI, p. 121). The Algerian species is slightly larger and one of the two specimens [i.e. specimen 11/78(3)] differs in the more clearly evolute inner whorls. Another resembling form is Eostaffella? sp.-Millerella? sp. of Gibshman and Akhmetshina (1990, pl. 3, figs. 17-19).

\section{Millerella aff. paraumbilicata \\ Manukalova et al., 1969 \\ Fig. 12 f-h}

Sample: SA 11.

Measurements:

Specimen No.wh.D(0) D(2) D(3) D L/D W.th. R.v. F.r. 24(2) $\quad 4.5(5) \quad-\quad \begin{array}{llllllll}176 & 284 & 608 & 0.47 & 16 & 320 & 0.45\end{array}$ $\begin{array}{lllllllll}49(1) & 4.5 & 35 & 168 & 312(625 ?) & - & 12 & 372 & 0.43\end{array}$ $\begin{array}{llllllllll}62(2) & 3.5 & 30 & 160 & 312 & 420 & 0.49 & 12 & 244 & 0.42\end{array}$

\section{Description}

Large shell in comparison with other fusulinoideans from the present locality. Inner whorls are thickly discoidal to lenticular; the ultimate discoidal whorl shows shallow (and wide) or deep umbilical depressions. The periphery is arched or (in middle whorls) arched to bluntly pointed. The first one or two whorls are at an angle to subsequent whorls. Adult specimens show outer whorls in contact or are slightly evolute. The spirotheca, except for the single-layered first whorl, consists of a tectum overlying a thicker, less dense, layer. The outer volutions show high, narrow, and, at the tunnel side, steep chomata; in the first whorls they are low and relatively wide.

\section{Comparisons}

This possibly new species is characterized by conspicuous - relatively high - chomata, loosely coiled volutions, a not entirely stable axis of coiling, and large size. Millerella paraumbilicata may be a related species, but is much smaller (up to 460 microns). Millerella citata (Bogush and Yuferev, 1962) could be related as well, but the one illustrated specimen of this species does not permit a detailed comparison. It probably has a larger proloculum and fewer volutions than the Algerian form.

\section{Plectostaffella Reitlinger, 1971}

Type species: Eostaffella? (Plectostaffella) jakhensis Reitlinger, 1971.

\section{Plectostaffella aff. varvariensis} (Brazhnikova and Potievska, 1948)

Fig. 13 a-s

Sample: SA 11.

Measurements:

$\begin{array}{lccccccccc} & \text { No.wh. } & \mathrm{D}(0) & \mathrm{D}(2) & \mathrm{D}(3) & \mathrm{D} & \text { L/D } & \text { W.th. } & \text { R.v. } & \text { F.r. } \\ \mathrm{m} & 4.1 & 25 & 101 & 176 & 325 & 0.43 & 8.5 & 185 & 0.38 \\ \mathrm{~s} & 0.4 & 2.5 & 10 & 20 & 47 & 0.05 & 1 & 27 & 0.04 \\ \mathrm{n}=24 & & 22 & 23 & 23 & 23 & 22 & 22 & & 23\end{array}$

\section{Description}

Specimens are discoidal or nautiliform showing wide and shallow, occasionally deep, umbilical depressions.

The periphery is flat or arched in the first whorl, mainly 

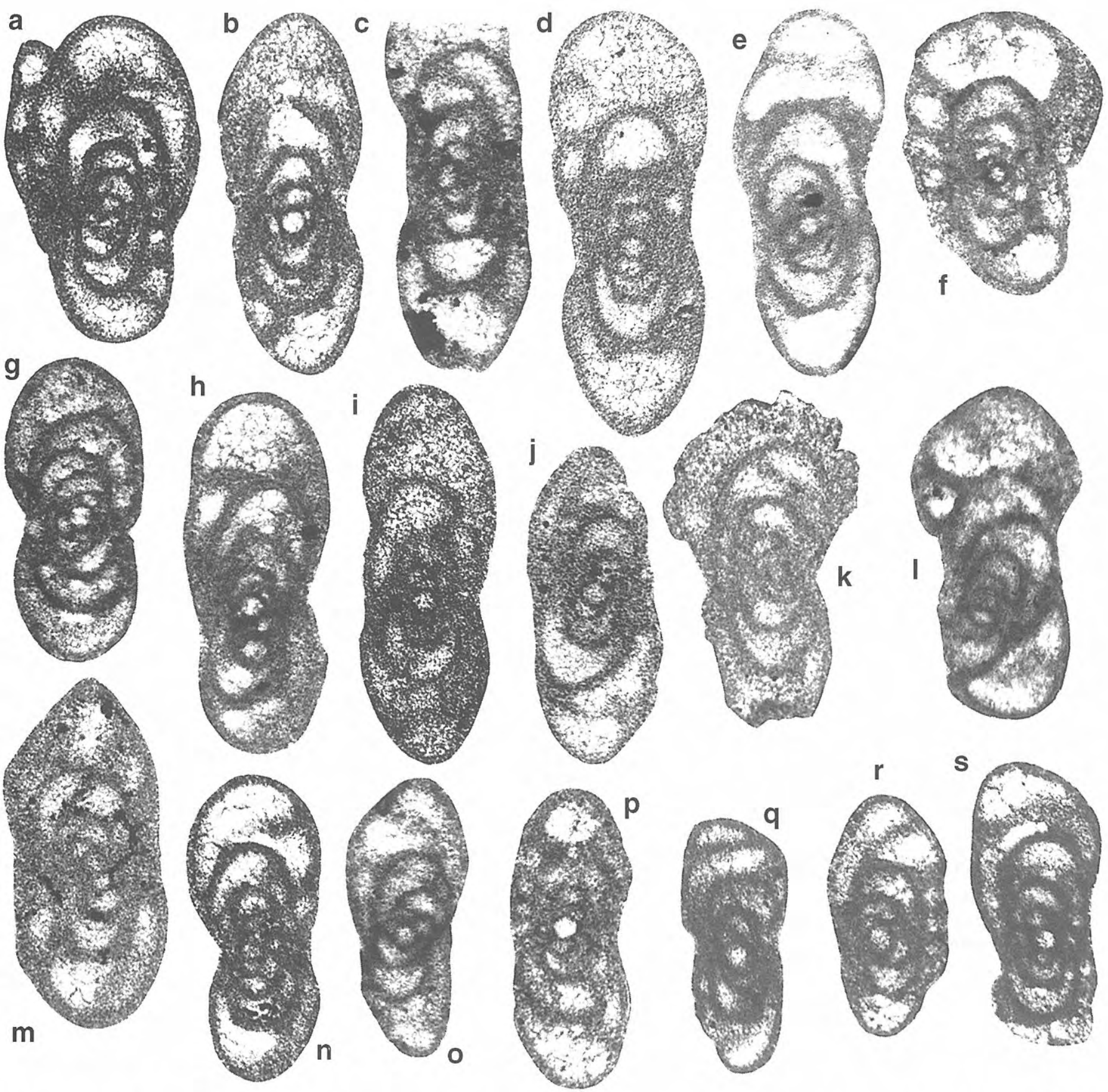

Figure 13. Plectostaffella aff. varvariensis (Brazhnikova et Potievska, 1948), specimens a. 11/35(2), b. 11/15(5), c. 11/46(2), d. $11 / 64(1)$, e. 11/52(2), f. 11/31(1), g. 11/35(1), h. 11/42(7), i. 11/99(1) j. 11/15(2), k. 11/36(2), l. 11/74(2), m. 11/63(4), n. 11/83(5), o. 11/46(1), p. 11/73(1), q. 11/81(5), r. 11/27(2), s. 11/83(2). Axial sections. All x160 (SA 11).

arched in the second and third, bluntly pointed to arched in the fourth, and again arched in the fifth whorl. After the first one or one and one half whorls the axis of coiling may have shifted up to 90 degrees; these shifts are less conspicuous in subsequent whorls. Coiling is mainly evolute (first whorl), slightly evolute, in contact, or just involute (second-fourth whorls), and usually (slightly) evolute (fifth whorl). The spirotheca is undifferentiated in the inner one to two whorls, but in subsequent whorls it consists of a tectum overlying a more translucent and thicker layer. The discontinuous chomata are low or of medium height and relatively wide.

\section{Comparisons}

The Algerian species, in comparison with Plectostaffella varvariensis, has a smaller diameter at corresponding volutions, and a smaller number of volutions. The Algerian specimens that show a relatively stable axis of coiling are often similar to Eostaffella varvariensis var. grandis Brazhnikova ms. (Brazhnikova, 1951, p. 92, pl. I, figs. 7,8). Equally similar is Eostaffella varvariensis var. umbonata Brazhnikova and Potievskaya (see Wagner et al., 1979). A description of this variety may have never been published. A related species could 

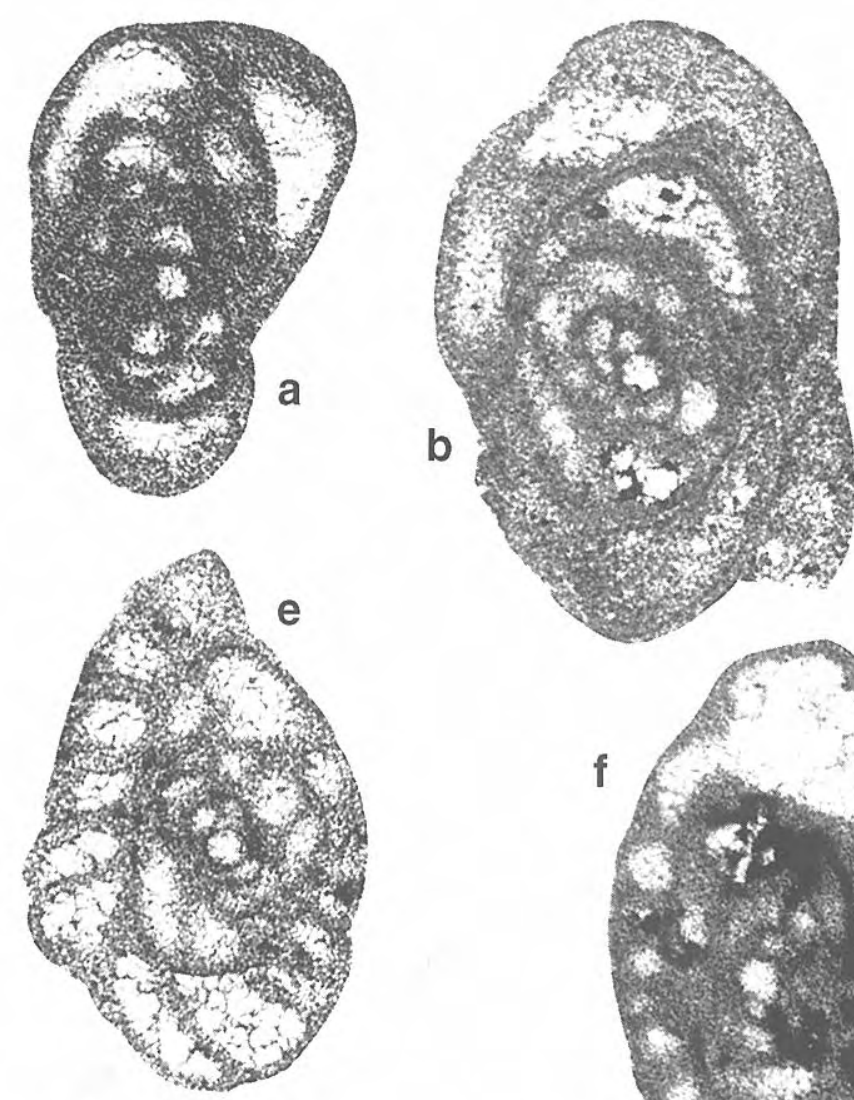

b

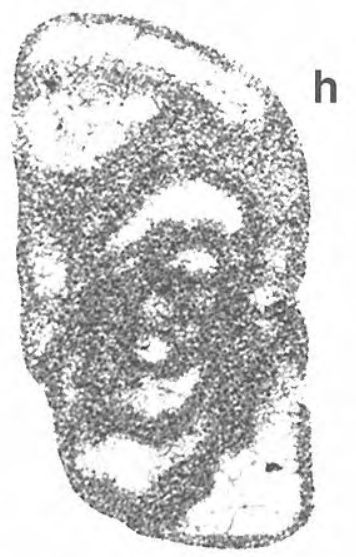

h
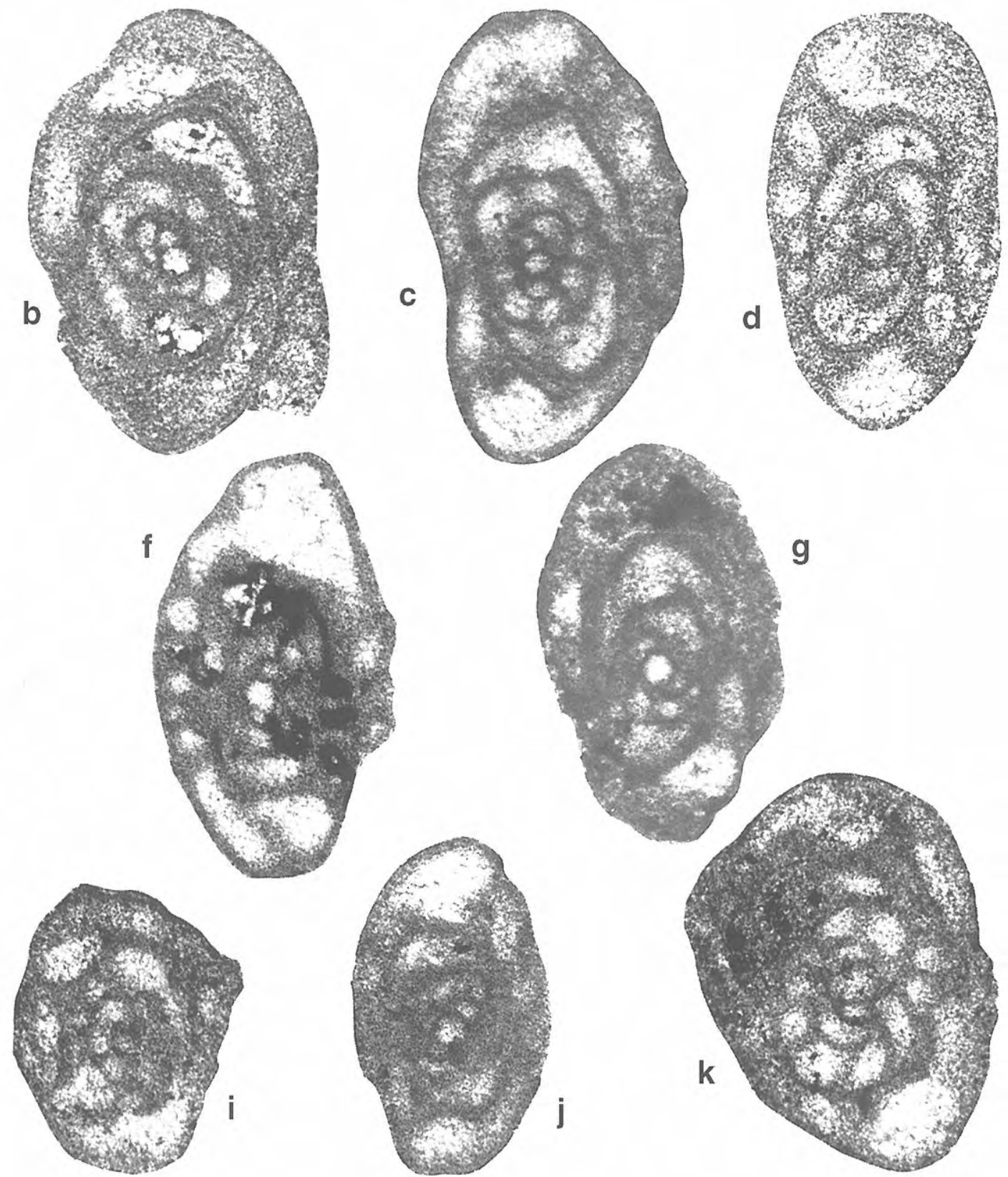

Figure 14. Plectostaffella jakhensis (Reitlinger, 1971), specimens a. 11/42(5), b. 11/29(4), c. 11/3(1), d. 11/44(7), e. 11/50(2), f. 11/63(2), g. 11/52(4), h. 11/27(1), i. 11/41(4), j. 11/60(3), k. 11/58(5). Axial sections. All x160 (SA 11).

be Plectostaffella ispaica Rumyantseva in Kulagina et al. (1992); especially the Algerian specimens 11/15(2) and 11/83(2) (Fig. 13 j,s) are similar. Eostaffella evolutica Rumyantseva, 1970 has less developed secondary deposits, fewer whorls, and a larger diameter at corresponding whorls.

Slender, partially evolute, specimens resemble also Plectomillerella subacuta Brazhnikova and Vdovenko, 1983.

Brazhnikova and Potievska (1948) noted the close similarity of their new species Eostaffella varvariensis to Eostaffella pseudostruvei. The similarity is indeed evident for the specimens of Plectostaffella varvariensis that show a relatively stable axis of coiling.

\section{Plectostaffella jakhensis (Reitlinger,1971)}

Fig. $14 \mathrm{a}-\mathrm{k}$

Sample: SA 11.

\section{Measurements:}

$$
\begin{array}{lccccccccc} 
& \text { No.wh. } \mathrm{D}(0) & \mathrm{D}(2) & \mathrm{D}(3) & \mathrm{D} & \text { L/D } & \text { W.th. } & \text { R.v. } & \text { F.r. } \\
\mathrm{m} & 4.0 & 30 & 123 & 208 & 373 & 0.59 & 11 & 207 & 0.53 \\
\mathrm{~s} & 0.4 & 4.5 & 16 & 31 & 46 & 0.07 & 1 & 28 & 0.07 \\
\mathrm{n}=11 & & & & & & 10 & 9 & & 10
\end{array}
$$

\section{Description}

Test develops from discoidal in the inner one to two whorls, to nautiliform in the outer whorls. Umbilical 


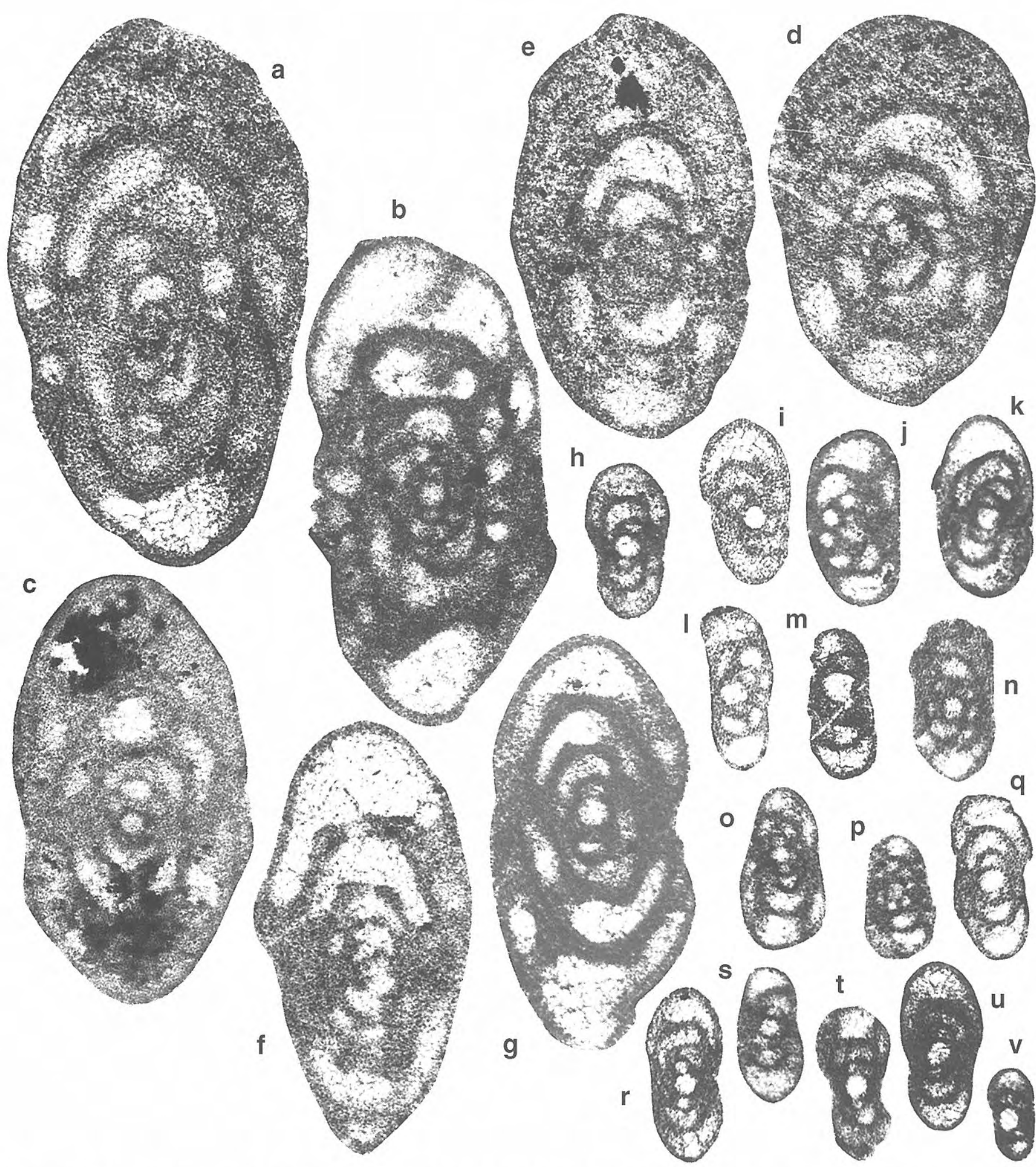

Figure 15. a-c. Plectostaffella? sp., specimens a. 11/62(1), b. 11/77(1), c. 11/22(1); d, e. Eostaffellina libera (Rumyantseva, 1970), specimens d. 11/4(3), e. 11/38; f, g. Eostaffella ex gr. parastruvei (Rauzer-Chernousova, 1948), specimens f. 11/5(1), g. 11/36(1); h-v. Endostaffella? sp., specimens h. 11/42(10), i. 11/8(1),j. 11/73(4), k. 11/32(4), I. 11/49(3), m. 11/89(4), n. 11/42(8), o. 11/42(9), p. 11/91(9), q. 11/4(4), r. 11/6(10), s. 11/41(5), t. 11/81(10), u. 11/91(4), v. 11/89(5). Axial sections. All x160 (SA 11).

depressions are generally absent. The periphery changes from mainly arched in the inner three whorls, towards mainly arched to bluntly pointed (rarely pointed) in the outer two whorls. Considerable shifts in the axis of coiling (angles up to 90 degrees) can be observed throughout growth. The trend is towards involute coiling: the first whorl shows opposite half-whorls in contact, or, less commonly, this whorl is evolute; subsequent whorls are progressively more 
involute, and the 4th and 5th whorls are invariably involute. Except for the first whorl, which is undifferentiated, a tectum may be observed overlying a thicker more translucent layer; occasionally, the wall seems undifferentiated throughout growth. Secondary deposits can be absent up to whorl 2.5; subsequent whorls show fairly well-developed chomata.

\section{Comparisons}

The specimens described by Manukalova et al. (1969) as Eostaffella paraprotvae Rauzer-Chernousova, 1948a, Eostaffella paraprotvae var. acuta var. nov., and Eostaffella aff. paraprotvae are quite close to the Algerian specimens. In the present work, as in Reitlinger (1971) and Groves (1988), they are assigned to Plectostaffella jakhensis. The similar Plectostaffella seslavica (Rumyantseva, 1970) may have less massive chomata. Specimens from the lower part of the Hassi Kerma Formation identified as Eostaffella (Plectostaffella)? sp. (van Ginkel, 1992, sample SA 19, p. 257, fig. 13) are close too, but differ in showing conspicuous umbilical depressions and a more stable axis of coiling.

\section{Plectostaffella? sp.}

Fig. 15 a-c

Sample: SA 11.

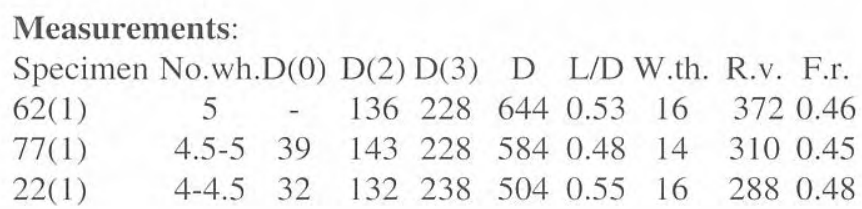

\section{Description}

The specimens are large in comparison with most other fusulinoidean specimens from the samples SA 13 and SA 11. The shell develops from discoidal in the inner two volutions to nautiliform or plano-nautiliform in subsequent whorls. Umbilical depressions are shallow or absent. The periphery is arched in the inner 2.5-3.5 whorls; arched or bluntly pointed in subsequent whorls. The axis of coiling may shift throughout growth, but large shifts occur only in the inner whorls; one specimen that has five whorls is planispiral from whorl 2.5 onwards. Coiling is evolute or in contact (first whorl), in contact or involute (second-fourth whorl) and involute (third-fifth whorl). A tectum overlying a thicker, less dense, layer may be observed from the second whorl onwards. Adjacent to the septa, the chomata are of medium height and show fairly steep slopes at the side of the narrow tunnel; more to the center of chambers secondary desposits are less developed, and tunnel and chomata become less distinctive as such.

\section{Comparisons}

The assignment of this form to Plectostaffella is questionable because it has a relatively stable axis of coiling. However, shape and development of chomata are reminiscent of Plectostaffella jakhensis. Somewhat similar species are Plectostaffella sp. nov. (Rumyantseva in Kulagina et al., 1992, pl. X, fig. 7) and Eostaffella parastruvei of Rumyantseva (1970, pl. VI, fig. 18). Eostaffella parastruvei (Rauzer-Chernousova, 1948b) differs by its slightly larger diameter [D=(400)600-1000 versus 500-650 microns] and less-developed secondary deposits.

\section{Eostaffellina Reitlinger, 1963}

Type species: Eostaffella protvae Rauzer-Chernousova, 1948 a.

\section{Eostaffellina cf. libera (Rumyantseva, 1970)}

Fig. 15 d, e

\section{Sample: SA 11.}

\section{Measurements:}

Specimen No.wh.D(0) D(2) D(3) D L/D W.th. R.v. F.r.

$\begin{array}{llllllllll}4(3) & 4-4.5 & 38 & 138 & 235 & 476 & 0.71 & 15 & 272 & 0.62\end{array}$

$\begin{array}{llllllllll}38 & 4-4.5 & - & 138 & 233 & 548 & 0.55 & 18 & 340 & 0.45\end{array}$

\section{Description}

Test thickly nautiliform; lateral sides curved; umbilical depressions absent. Periphery arched, or, in the final whorl, arched to bluntly pointed. The inner one to two whorls are at an angle to subsequent whorls. Coiling is involute, except for the inner whorls, which, in one of the two specimens, may be evolute. The wall is either undifferentiated, or, more rarely, a tectum overlying a thicker layer can be distinguished. The chomata are discontinuous, low or (adjacent to the tunnel openings of the septa) moderately high.

\section{Comparisons}

The two Algerian specimens are intermediate between the Bashkirian forms Eostaffella (Eostaffellina) libera Rumyantseva, 1970 and Eostaffella paraprotvae var. grandis Manukalova et al., 1969; they differ from both species in that the Algerian specimens have flat or slightly raised axial areas and no umbilical depressions. The lower part of the Hassi Kerma Formation, at sampling station SA 17, contains the similar Eostaffella (Eostaffellina) sp. (van Ginkel, 1992, cf. specimen SA17/16, fig. 13/12).

\section{Eostaffella Rauzer-Chernousova, 1948b}

Type species: Staffella (Eostaffella) parastruvei RauzerChernousova, 1948b.

\section{Eostaffella ex gr. parastruvei (Rauzer-Chernousova, 1948b)}

Sample: SA 11.
Fig. 15 f,g 
Measurements:

Specimen No.wh.D(0) D(2) D(3) D L/DW.th. R.v. F.r. $\begin{array}{llllllllll}5(1) & 4.5 & - & 120 & 212 & 506 & 0.51 & 12 & 296 & 0.43\end{array}$ $\begin{array}{llllllllll}36(1) & 4.5 & 39 & 128 & 232 & 488 & 0.47 & 14 & 280 & 0.41\end{array}$

\section{Description}

Test nautiliform; umbilical depressions absent, or shallow and narrow. Peripheral rim arched in the inner two whorls, and arched to pointed in the outer whorls. The first whorls show slight shifts in the axis of coiling; later whorls are planispiral. Volutions are in contact in the inner two whorls, involute or in contact in the outer whorls. Spirotheca single-layered in the inner two whorls and with tectum and a lower, less dense layer, in outer whorls. Discontinuous(?) chomata are present in the outer three whorls; they are low or of medium height and not sharply delimited at the side of the relatively wide tunnel (low slopes at the tunnel side). Somewhat denser areas occur near the poles (reminiscent of Mediocris).

\section{Comparisons}

The two Algerian specimens are quite similar to Eostaffella ex gr. radiata (Brady, 1876) emend. Armstrong and Mamet (1977; pl. 35, figs. 5,7). The radiata group of Armstrong and Mamet includes Eostaffella mosquensis Vissarionova, 1948. The type specimen of Eostaffella mosquensis in comparison with the Algerian specimens is smaller, more tightly coiled, and has slightly more (five) volutions. Other differences may be the even less developed secondary deposits and the absence of a clear tunnel in Eostaffella mosquensis. In view of the sometimes acute peripheral rim and the distinct secondary deposits of the Algerian specimens, the relationship with Eostaffella mosquensis attenta Ganelina, 1951 (pl. 2, fig. 7) and E. mosquensis sublata Ganelina, 1951 (pl. 2, fig. 10) may be closer. Two specimens identified as Eostaffella mosquensis by Matsusue (1992, figs. 3/18, 3/19) are similar too; they probably have a larger diameter at corresponding volutions and less developed secondary deposits. Other related forms may be Eostaffella kanmerai (Igo, 1957), which shares the small and dense deposits in the polar regions, and Eostaffella chusovensis Kireeva, 1951.

\section{Eostaffella aff. chusovensis Kireeva, 1951 Fig. 16 a-m}

Sample: SA 11.

\section{Measurements:}

$\begin{array}{lccccccccc} & \text { No.wh. } & \mathrm{D}(0) & \mathrm{D}(2) & \mathrm{D}(3) & \mathrm{D} & \text { L/D } & \text { W.th. } & \text { R.v. } & \text { F.r. } \\ \mathrm{m} & 4.4 & 30 & 120 & 211 & 452 & 0.47 & 11 & 255 & 0.42 \\ \mathrm{~s} & 0.3 & 3 & 13 & 19 & 56 & 0.05 & 2 & 32 & 0.04 \\ \mathrm{n}=19 & & 16 & & & & 18 & 18 & & \end{array}$

\section{Description}

The shell is discoidal, nautiliform or lenticular; umbilical cavities are shallow or absent. The peripheral rim develops from predominantly arched (first three whorls) towards arched to bluntly pointed (last two whorls) (Table 15).

\begin{tabular}{lrrrrr}
\hline Wh.no. & 1 & 2 & 3 & 4 & 5 \\
\hline S & $\mathbf{4 3}$ & 39 & 15 & 8 & \\
A & $\mathbf{4 8}$ & $\mathbf{4 5}$ & $\mathbf{5 8}$ & 29 & 36 \\
A(blp) & 9 & 16 & 24 & $\mathbf{4 5}$ & $\mathbf{5 0}$ \\
Blp & & & 3 & 18 & 14 \\
P(blp) & & & & & \\
P & & & & & \\
\hline
\end{tabular}

Table 15. Development of the degree of angularity of the peripheral rim in Eostaffella aff. chusovensis (explanation as in Table 5).

\begin{tabular}{lrrrrr}
\hline Wh.no. & 1 & 2 & 3 & 4 & 5 \\
\hline E & $\mathbf{6 9}$ & 10 & 6 & & \\
C & 31 & $\mathbf{7 7}$ & 44 & 21 & 27 \\
I & & 13 & $\mathbf{5 0}$ & $\mathbf{7 9}$ & $\mathbf{7 3}$ \\
\hline
\end{tabular}

Table 16. Development of evolute versus involute coiling in Eostaffella aff. chusovensis (explanation as in Table 4).

Coiling is either planispiral or, more commonly, the axis of coiling is not entirely stable. Some specimens show clearly an angular shift of the axis between first and second whorls; others show conspicuous axial shifts in the adult stage. The spiral develops from mainly evolute (first whorl), in contact (second whorl), to mainly involute (third-fifth whorls) (Table 16). From whorl 1.5 onwards, the wall contains a tectum, overlying a thicker and more translucent layer. A few specimens show an undifferentiated wall throughout growth. Discontinuous chomata are either low and relatively wide, or, close to the tunnel openings, of medium height.

\section{Comparisons}

The Algerian species resembles Millerella chomatifera (Kireeva, 1951) and Eostaffella chusovensis. The former has better developed chomata and a more stable axis of coiling. Eostaffella chusovensis is seemingly closer to the Algerian species than Millerella chomatifera, but the number of whorls of Eostaffella chusovensis is lower, the proloculum larger, the diameter at corresponding whorls greater, and the chomata seem less developed. Very similar is also a relatively slender specimen of Eostaffella chusovensis illustrated by Manukalova et al. (1969, pl. X, fig. 4).

\section{Endostaffella Rozovskaya, 1961}

Type species: Endothyra parva von Möller, 1879.

\section{Endostaffella sp.}

Fig. 15 h-v

Sample: SA 11. 

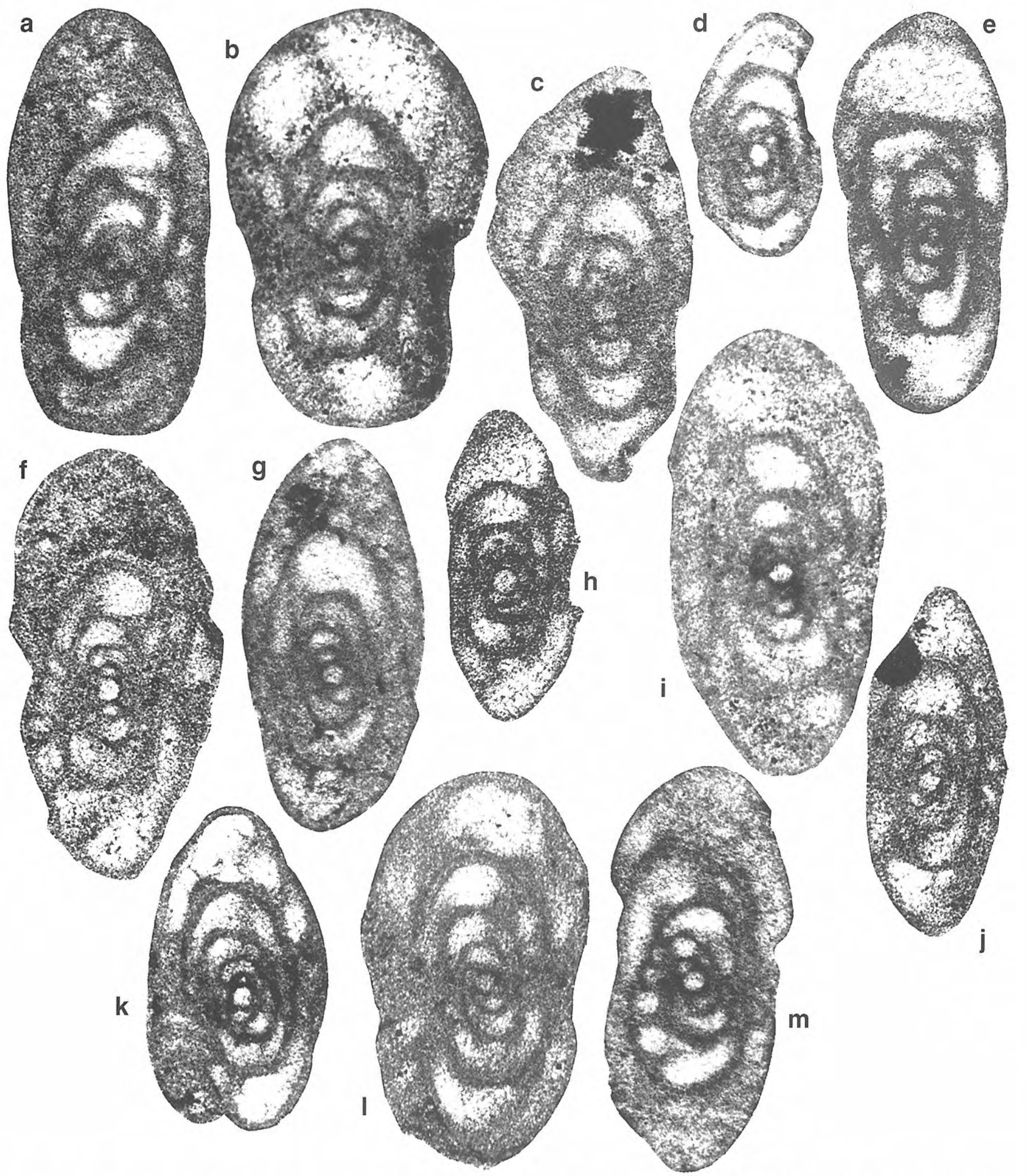

Figure 16. Eostaffella aff. chusovensis Kireeva,1951, specimens a. 11/6(2), b. 11/75(3), c. 11/59(1), d. 11/18(2), e. 11/15(1), f. 11/91(13), g. 11/42(1), h. 11/91(2), i. 11/73(2), j. 11/28, k. 11/15(4), l. 11/65(1), m. 11/6(1). Axial sections. All x160 (SA 11).

Measurements:

$\begin{array}{ccccccccc}\text { No.wh. } & \mathrm{D}(0) & \mathrm{D}(2) & \mathrm{D}(3) & \mathrm{D} & \text { L/D } & \text { W.th. } & \text { R.v. } & \text { F.r. } \\ 3.0 & 28 & 112 & 171 & 185 & 0.50 & 6.5 & 104 & 0.44 \\ 0.4 & 4 & 119 & 23 & 27 & 0.06 & 1.25 & 17 & 0.05\end{array}$

$\begin{array}{lll}n=19 & 18 & 13\end{array}$

18

Description

Specimens are short discoidal and generally slightly 
umbilicate. The peripheral rim is arched throughout growth or, in outer whorls, arched to bluntly pointed. About one third of the specimens of at least two and one half whorls are planispiral; others show a conspicuous angular shift (up to 90 degrees) of the axis of coiling between whorls 1 and 2, or its position oscillates throughout growth. The (sagittal) first whorl of axial sections usually has five bulbous chambers and septa at an angle roughly perpendicular to the spirotheca. The first whorl is generally evolute; subsequent whorls are usually in contact. Half the specimens with about three volutions have an undifferentiated spirotheca; the others show a tectum in the ultimate volution. Secondary deposits, if present, are very weak and observed only in the outer one or two whorls; they may be low and wide pseudochomata. In nearly half of the specimens that have at least two and a half whorls, secondary deposits are absent.

\section{Comparisons}

Very similar, possibly conspecific, is Eostaffella prisca var. minor Saurin, 1970. Closely related forms are perhaps Plectogyra bradyi (Mikhailov,1939) forma minima Manukalova et al., 1969, and Eostaffella (Eostaffella) asymmetrica Potievskaya, 1974. These species have been described from Lower Bashkirian strata from Laos/N Vietnam and Ukraina respectively. Eostaffella (E.) asymmetrica differs in its smaller L/D ratio $(0.40-0.46$ versus $0.38-0.61)$.

\section{Remarks}

The wall of Endostaffella has been reported to be undifferentiated, but in some species (e.g. Endostaffella delicata Rozovskaya, 1963) a tectum is apparently present. The presence of secondary deposits and a tectum in a substantial number of the Algerian specimens may point to a highly evolved member of the genus. On the other hand, these specimens may not be Endostaffella at all, but juveniles of Plectostaffella aff. varvariensis or Millerella ex gr. pseudostruvei which are also present in the sample.

\section{Mediocris Rozovskaya, 1961}

Type species: Eostaffella mediocris Vissarionova, 1948.

$$
\begin{gathered}
\text { Mediocris breviscula (Ganelina, 1951) } \\
\text { Fig. } 5 \text { q, } 12 \text { i-n }
\end{gathered}
$$

Sample: SA 13, specimen 3(4); SA 11, 8 specimens.

\section{Measurements:}

No.wh. $\mathrm{D}(0) \mathrm{D}(2) \mathrm{D}(3)$ D $\quad$ L/D W.th. R.v. F.r.

$\begin{array}{lccccccccc}\text { Spec.3(4)2-2.5 } & 27 & & 145 & 0.34 & 4 & 84 & 0.29 & \\ \mathrm{~m} & 2.4 & 31 & 152 & 244 & 201 & 0.40 & 6 & 113 & 0.34 \\ \mathrm{~s} & 0.4 & 5.5 & 27 & & 31 & 0.04 & 0.9 & 20 & 0.04 \\ \mathrm{n}=8 & & & & 2 & & & & & \end{array}$

\section{Comparisons}

The species from SA 11 has been assigned to
Mediocris breviscula, despite its smaller maximum values for diameter and number of whorls, and the slightly smaller average length/diameter ratio. In comparison with the closely related Mediocris evolutis Rozovskaya,1963, the Algerian specimen has fewer whorls, and also the outer whorl is less evolute. The single specimen from SA 13 resembles the smaller specimens of both Mediocris evolutis and M. breviscula.

\section{ACKNOWLEDGEMENTS}

Investigations were made possible by a grant from the Pieter Langerhuizen Lambertuszoon fund (The Netherlands). The typescript was read by Drs. P.L. Brenckle, J.R. Groves, B.L. Mamet, and E. Villa. Their comments leaded to significant improvement.

\section{REFERENCES}

Aisenverg, D.E., Brazhnikova, N.E., Vassilyuk, N.P., Reitlinger, E.A., Fomina, E.V. and Einor, O.L. 1979. The Serpukhovian stage of the Lower Carboniferous of the USSR. In: The Carboniferous of the U.S.S.R. (Coord. R.H. Wagner, A.C. Higgins, S.V. Meyen). Yorkshire Geological Society, 4, 43-59

Anisgard, H.W. and Campau, D.E. 1963. Paramillerella thompsoni n.sp. from Michigan and a redefinition of Paramillerella. Cushman Foundation for Foraminiferal Research, Contributions, 14, 99-108.

Armstrong, K.A. and Mamet, B.L. 1977. Carboniferous microfacies, microfossils, and corals, Lisburne Group, Arctic Alaska. Geological Survey Professional Paper 849, 144 pp.

Bogush, O.I. and Yuferev, O.V. 1962. Foraminifers and stratigraphy of Carboniferous deposits in Karatau and Talasskiy Alatau [in Russian]. Trudy, Akademiya Nauk SSSR, Sibirskoe otdelenie, Institut Geologiy i Geofizikiy, 234 pp.

Brady, H.B. 1876. A monograph of Carboniferous and Permian Foraminifera (the genus Fusulina excepted). Palaeontological Society Publications, London, 30, 166 pp.

Brazhnikova, N.E. 1951. Material for the examination of the foraminiferal fauna from the western parts of the Donets Basin [in Russian]. Trudy Akademiya Nauk USSR, Institut Geologicheskikh Nauk, Stratigrafii $i$ Paleontologii Seriya, 5, 73-107.

Brazhnikova, N.E. and Potievska, P.D. 1948. Results of the examination of Foraminifera from borehole samples at the western boundary of the Donets Basin [in Ukrainian]. Trudy Akademiya Nauk USSR, Institut Geologicheskikh Nauk, Stratigrafii i Paleontologii Seriya, 1 (2), 76-103.

Brazhnikova, N.E. and Vdovenko, M.V. 1983. Foraminifera. In: Upper Serpukhovian substage in the Donets Basin, Paleontological characteristics [in Russian] (Coord. D.E. Aisenverg). Akademiya Nauk Ukrainskoi SSR, Institut Geologicheskikh Nauk, 42-68. 
Brazhnikova, N.E., Vakarchuk, G.I., Vdovenko, M.V., Vinnichenko, L.V., Karpova, M.A., Kolomiez, J.L., Potievskaya, D., Rostovzeva, L.F. and Tsjevchenko, G.D. 1967. Microfaunistic guide horizons of the Carboniferous and Permian deposits of the DnjeprDonets Basin [in Russian] (Coord. D.E. Aisenverg) Naukova Dumka, Kiev, 9-195.

Brenckle, P.L. and Groves, J.R. 1981. Evolution of Eostaffellid foraminifers in late Chesterian (Late Mississipian) strata of the North American Midcontinent. Geological Society of America, Abstracts with Programs, Cincinnati Meeting, 13, 416.

Chang, Lin-Hsin 1962. Fusulinids from the Howchow Limestone, Hohsien, Anhni [in Chinese with English summary]. Acta Palaentologica Sinica, 10, 433-441.

Chen, X. and Wang, J. 1983. The fusulinids of the Maping Limestone of the Upper Carboniferous from Yishan, Guangxi [in Chinese with a summary in English]. Palaeontologica Sinica, New Series B, 19, 139 pp.

Durkina, A.V. 1959. Foraminifera of the Lower Carboniferous deposits of the Timan-Pechora province [in Russian]. Microfauna USSR, Vsesoyuznii Neftyanoi Nauchno-Issledovatel'skii Geologo-Razvedochnii Instituta (VNIGRI), Leningrad, Trudy, Novaya Seriya, 136 (10), 132-335.

Dutkevich, G.A. 1934. On the stratigraphy of the Middle Carboniferous of the Urals [in Russian]. Vsesoyuznii Neftyanoi Nauchno-Issledovatel'skii GeologoRazvedochnii Instituta (VNIGRI), Leningrad, Trudy, Seriya A, 55, 1-41.

Ektova, L.A. 1976. Materials and arguments for the age division of the Middle Carboniferous. In: Stratigraphy and Paleontology of the Carboniferous [in Russian]. VSEGEI, Leningrad, Trudy, Novaya Seriya, 247, 70-111.

Ganelina, R.A. 1951. Eostaffella and Millerella from the Viséan and Namurian stages (Lower Carboniferous) of the western flank of the Moscow Basin [in Russian]. Vsesoyuznii Neftyanoi Nauchno-Issledovatel'skii Geologo-Razvedochnii Instituta (VNIGRI), Leningrad, Trudy, Novaya Seriya, 56, 179-212.

Gibshman, N.B. and Akhmetshina, L.Z. 1990. Micropaleontologic basis for determination of the MidCarboniferous boundary in the North Caspian syneclise (USSR). Courier Forschungsinstitut Senckenberg, 130, 273-295.

Ginkel, A.C. van 1965. Carboniferous fusulinids from the Cantabrian Mountains (Spain). Leidse Geologische Mededelingen, 34, $225 \mathrm{pp}$.

Ginkel, A.C. van 1986a. Carboniferous fusulinids of the Oued el Hamar Formation (Colomb-Béchar, Algeria). Proceedings of the Koninklijke Nederlandse Akademie van Wetenschappen, Series B, 89, 201-241.

Ginkel, A.C. van 1986b. Fusulinid Foraminifera of Westfalian $\mathrm{C}$ age near the top of the Kenadza strata (Colomb-Béchar, Algeria). Proceedings of the Koninklijke Nederlandse Akademie van Wetenschappen, Series B, vol. 89, 313-335.

Ginkel, A.C. van 1987. Systematics and biostratigraphy of the Lena Formation (Carboniferous) near Puebla de Lillo (León, NW Spain). Proceedings of the Koninklijke
Nederlandse Akademie van Wetenschappen, Series B, 90, 189-276.

Ginkel, A.C. van 1989. Carboniferous fusulinids from the upper part of the Hassi Kerma Formation (ColombBéchar, Algeria). Proceedings of the Koninklijke Nederlandse Akademie van Wetenschappen, Series B, 92, 313-362.

Ginkel, A.C. van 1992. Carboniferous fusulinids from the lower part of the Hassi Kerma Formation (ColombBéchar, Algeria). Proceedings of the Koninklijke Nederlandse Akademie van Wetenschappen, Series B, 95, 207-266.

Groves, J.R. 1984. Foraminifers and Biostratigraphy of the Arco Hills, Bluebird Mountain, and lower Snaky Canyon Formations (Mid-Carboniferous) of east-central Idaho. Journal of Foraminiferal Research, 14, 282-302.

Groves, J.R. 1988. Calcareous foraminifers from the Bashkirian strata (Middle Carboniferous, South Urals) and their significance for intercontinental correlations and the evolution of the Fusulinidae. Journal of Paleontology, 62, 368-399.

Groves, J.R. 1991. Fusulinacean biostratigraphy of the Marble Falls Limestone (Pennsylvanian), western Llano region, central Texas. Journal of Foraminiferal Research, 21, 67-95.

Grozdilova, L. and Lebedeva, N.S. 1950. Some species of Staffella from the Middle Carboniferous of the western slope of the Ural Mountains [in Russian]. Mikrofauna SSSR, Vsesoyuznii Neftyanii Nauchno-Issledovatel'skii Geologo-Razvedochnii Instituta (VNIGRI), Trudy, New Series, 50 (3), 5-46.

Grozdilova, L. and Lebedeva, N.S. 1954. Foraminifera from the Lower Carboniferous and Bashkirian Stage of the Middle Carboniferous of the Kolvo-Vishera area [in Russian]. Mikrofauna SSSR, Vsesoyuznii Neftyanii Nauchno-Issledovatel'skii Geologo-Razvedochnii Instituta (VNIGRI), Trudy, New Series, 81 (7), 4-203.

Grozdilova, L. and Lebedeva, N.S. 1960. Foraminifera from the Carboniferous of the western slopes of the Ural and Timan Mountains (Atlas of the most characteristic species) [in Russian]. Gostoptekhizdat (Leningradskoe otdelenie), Mikrofauna SSSR, Vsesoyuznii Neftyanii Nauchno-Issledovatel'skii Geologo-Razvedochnii Instituta (VNIGRI), Trudy, New Series, 150, 3-264.

Higgins, A.C. 1975. Conodont zonation of the late Viséanearly Westphalian strata of the south and central Pennines of northern England. Bulletin of the Geological Survey of Great Britain, 53, 3-90.

Hoare, R.D. and Sturgeon, M.T. 1994. Small fusulinids from the Pennsylvanian of Ohio. Journal of Paleontology, 68 (Supplement to no. 5) Part II of II, The Paleontological Society Memoir 38, 21 pp.

ICZN (International Commission on Zoological Nomenclature) 1999. International Code of Zoological Nomenclature, 4th edition, $306 \mathrm{pp}$.

Igo, H. 1957. Fusulinids of Fukuji, southeastern part of the Hida Massif, Central Japan. Science Reports, Tokyo, Kyoiku Daigaku, Section C, 5 (47), 153-246.

King, W.E. 1984. Millerella sandersoni, a new name for Millerella extensus King, 1973. Journal of Paleontology, 
58, 1421 .

Kireeva, G.D. 1949. Some new species of fusulinids from the Carboniferous limestones of the central part of the Donbass area [in Russian]. Trudy GeologoIssledovatelskogo, Glavuglerazvedka, Ugletekhizdat, 6 , 25-55.

Kireeva, G.D. 1951. In: Middle Carboniferous fusulinids of the Russian Platform and adjacent regions [in Russian] (D.M. Rauzer-Chernousova et al). Izdatel'stvo Akademiya Nauk SSSR, Institut Geologicheskikh Nauk, Ministerstvo Neftyanoi Promysjlennosti SSSR, 48-63.

Kulagina, E.I., Rumyantseva, Z.S., Pazuxin, V.N. and Kochetova, N.N. 1992. Lower/Middle Carboniferous boundary in the south Urals and central Tjan'-Tsjane [in Russian]. Rossijskaya Akademiya Nauk, Uralskoe otdelenie, Bashkirskij Nauchnyj Centr, Institut Geologii, Moscou "Nauka", 110 pp.

Legrand-Blain, M. 1967. Précisions sur la stratigraphie de la série des calcaires de Djebel Béchar (NamurienMoscovien) à l'Est de Béchar (Algérie). Bulletin Société Géologique de France, 7(9), 298-306.

Legrand-Blain, M. 1986. Spiriferacea (Brachiopoda) Viséens et Serpukhoviens du Sahara Algérien. Biostratigraphie du Paléozö̈que, 5, 85 pp.

Lemosquet, Y. et Pareyn, C. 1975. Karst et Chenaux de Ravinement dans le Carbonifère Marin du Bassin de Béchar et de ses Bordures (Sud-Oranais, Algérie). III Réunion Annuelle des Sciences de Terre, Montpellier, 230.

Lemosquet, Y. et Pareyn, C. 1985. Béchar Basin. In: North Africa chapter (Coord. M. Weyant). In: Carboniferous of the World (Coord. C.M. Martinéz Díaz, R.H. Wagner, C.F. Winkler Prins, L.F. Granados). Adaro, IGME, Madrid, 2, 306-315.

Lys, M. 1976. Valorisation par microfaunes du Bashkirien inférieur (Namurien B) (sous-zone R2) dans le Bassin Houiller du Nord de la France (Groupes de Douai et Valenciennes). Annales de la Société Géologique Nord, 96, 379-385.

Lys, M. 1979. Micropaléontologie (Foraminifères) des formations marines du Carbonifère Saharien. Huitième Congrès International de Stratigraphie et de Géologie Carbonifère, Compte Rendu, Moscow (1975), 2, 37-37.

Lys, M. 1985. Foraminifera. In: North Africa chapter (Coord. M.Weyant). In: Carboniferous of the World (Coord. C.M. Martinéz Díaz, R.H. Wagner, C.F. Winkler Prins, L.F. Granados). Adaro, IGME, Madrid, 2, 354364.

Mamet, B.L. 1981. Note taxonomique sur Zellerinella nomen novum (Foraminiferida, Eostaffellidae). Geobios, 14, 140 .

Mamet, B.L., Madi, A., Bourque, P.A. et Sebbar, A. 1995. Foraminifères carbonifères du Grand Erg Occidental, Bassin de Béchar, Algérie. Bulletin de la Societé Belge de Géologie, 103, (1994), 51-61.

Manger, W.L., Weyant, M. and Pareyn, C. 1985. MidCarboniferous Ammonoid Biostratigraphy, Béchar Basin, Algeria. Courier Forschungsinstitut Senckenberg, 74, 181-196.

Manukalova, M.F. 1950. Description of some new fusulinid species from the Middle Carboniferous of the Donets Basin [in Russian]. Ministerstvo Ugol'noi Promytsjlennosti SSSR, Ugletekhizdat, MoskvaKharkov, 175-219.

Manukalova, M.F., Iljina, M.T. and Serezhnikova, T.D. 1969. Atlas of Foraminifera of the Middle Carboniferous of the Dnjepr-Donets Basin [in Russian]. Ministerstvo geologii USSR, Ukrainskii Nauchno-Issledovatelskii Geologo-Razvedochnii Instituta (Ukr.NIGRI), Nedra, Leningrad, $288 \mathrm{pp}$.

Marshall, F.C. 1969. Lower and Middle Pennsylvanian fusulinids from the Bird Spring Formation near Mountain Springs pass, Clark county, Nevada. Brigham Young University, Geological Studies, 16(1), 97-154.

Maslo, A.I. 1993. Some new species of foraminifers from the Lower/Middle Carboniferous boundary of the Donbass [in Russian]. Ukrainskoi Paleontologicheskii Zhurnal, 23, 3-7.

Maslo, A.I. et Vachard, D, 1997. Inventaire critique des Eostaffellinae (Foraminifères) du Carbonifère. Revue de Micropaléontologie, 40, 39-69.

Matsusue, K. 1992. The Mid-Carboniferous Boundary in the Akiyoshi Limestone Group, southwest Japan, based on foraminifers. In: Studies in benthic Foraminifera. Benthos '90, Sendai, 1990, Tokai University Press, 381388.

Mikhailov, A.V. 1939. To the characteristics of the genera of Lower Carboniferous foraminifera on the territory of the USSR. In: The Lower Carboniferous deposits of the northwestern slope of the Moscow Basin [Russian with English summary] (Coord. S.F. Maliavkin). Leningrad, Geological Trust, Symposium 3, 47-62.

Möller, V. von 1879. Die Foraminiferen des russischen Kohlenkalks. Académie Impérial des Sciences, St. Pétersbourg, Mémoir, série 7, 27(5), 131 pp.

Moore, W.L. 1964. Notes on the morphology and taxonomic position of the fusulinid Millerella marblensis Thompson. Journal of Paleontology, 38, 294-305.

Nemyrovska, T.I. 1999. Bashkrian conodonts of the Donets Basin, Ukraine. Scripta Geologica, 119, 115 pp.

Nemyrovskaya, T.I. 1982. Conodonts near the boundary between Lower and Middle Carboniferous of Donets Basin. In: Biostratigraphic data for a Mid-Carboniferous boundary (Coord. W.H.C. Ramsbottom, W.B. Saunders and B. Owens). Meeting of IUGS Subcommission on Carboniferous Stratigraphy, Leeds, 1981, 15-18.

Niko, S. 1987. Early Carboniferous Eostaffella (primitive Fusulinacea) from the Ichinotani Formation, Fukuji district, central Japan. Transactions and Proceedings, Palaeontological Society of Japan, Tokyo, New Series, 147, 117-130.

Ota, M. 1971. Faunas and correlation of the "Uzura" Quarry Limestone of Akiyoshi, southwest Japan. Part II, Fusulinian Fauna. Akiyoshi-dai Science Museum, 7, 6574.

Pareyn, C. 1961. Les massifs carbonifères du Sahara SudOranais. Publications du Centre de Recherches Sahariennes. Série Géologique no. 1; I, 326 pp.; II, 244 pp.

Popov, A.V. 1979. Carboniferous ammonoids of the Donets 
Basin and their stratigraphic significance [in Russian]. Trudy Vsesoyuznogo Geologicheskogo Instituta, Nedra, Leningrad, 220, 119 pp.

Potievskaya, P.D. 1964. Some Fusulinidae and small foraminifers from Bashkirian sediments of the greater Donets Basin. In: Material and fauna from the Upper Palaeozoic of the Donbass [in Russian] (Coord. Aisenverg, D.E.). Akademiya Nauk Ukrainskoi SSR, Kiev, Trudy Institut Geologicheskikh Nauk, Seriya Stratigrafii i Paleontologii, 48(2), 31-59.

Potievskaya, P.D. 1974. On the fauna of Ozawainellidae from the Bashkirian Stage in the northern outskirts of the Donets Basin. In: Fossil fauna and flora from Ukraina [in Ukrainian]. Akademiya Nauk Ukrainskoi SSR, Kiev, Trudy Institut Geologicheskikh Nauk, 2, 32-52.

Putrya, F.S. 1956. Stratigraphy and foraminifers of Middle Carboniferous strata of the eastern Donbass [in Russian]. Vsesoyuznii Neftyanoi Nauchno-Issledovatel'skii Geologo-Razvedochnii Instituta (VNIGRI), Trudy, Leningrad, SSSR; Mikrofauna, 98(8), 333-485.

Rauzer-Chernousova, D.M. 1948a. Some new species of foraminifera from the Lower Carboniferous deposits of the Moscow Basin. In: Stratigraphy and foraminifera of the Lower Carboniferous of the Russian Platform and the Cis-Ural region [in Russian] (Coord. D.M. RauzerChernousova). Akademiya Nauk SSSR, Institut Geologicheskikh Nauk, Trudy, Geologicheskaya Seriya, 19(62), 227-238.

Rauzer-Chernousova, D.M. 1948b. Foraminifera from the Carboniferous deposits of central Kazakhstan, U.S.S.R. [in Russian]. Akademiya Nauk SSSR, Institut Geologicheskikh Nauk, Trudy, Geologicheskaya Seriya, 21(66), 27 pp.

Rauzer-Chernousova, D.M. 1951. In: Middle Carboniferous fusulinids of the Russian Platform and adjacent regions [in Russian]. (D.M. Rauzer-Chernousova, G.D. Kireeva, G.E. Leontovich, N.D. Grizlova, T.P. Safonova, E.I. Chernova). Izdatel'stvo Akademiya Nauk SSSR, Institut Geologicheskikh Nauk, Ministerstvo Neftianoj Promysjlennosti SSSR, 59-66.

Rauzer-Chernousova, D.M. and Belyaev, G.M. 1936. In: Die oberpalaeozoischen Foraminiferen aus dem Petschoralande der Westabhang des Nord-Urals [Russian with summary in German] (D.M. RauzerChernousova, G.M. Belyaev and E.A. Reitlinger). Trudy Poliarnaya Komissii, Akademiya Nauk SSSR, 28, 179, 221.

Reitlinger, E.A. 1956. The new family Lasiodiscidae. Akademiya Nauk SSSR, otdelenie Geologii, Geophiziki, $i$ Geokhimii, Voprosy Mikropaleontologii, Moskva, 1, 6979.

Reitlinger, E.A. 1961. Stratigraphy of Middle Carboniferous strata of well no. 1 (Krasnopoliana, central Volga area) [in Russian]. Akademiya Nauk SSSR, Geologicheskikh Instituta, Regional'naya Stratigrafiya SSSR, 5, 218-260.

Reitlinger, E.A. 1963. On the unique paleontological criterium for establishing the boundaries of the Lower Carboniferous on the basis of foraminifera [in Russian]. Akademiya Nauk SSSR, otdelenie Geologii, Geophiziki, $i$ Geokhimii, Voprosy Mikropaleontologii, Moskva, 7, 22-
56.

Reitlinger, E.A. 1971. Some problems of systematics in the light of evolution stages of upper Paleozoic Foraminifera [Russian with summary in English]. Akademiya Nauk SSSR, otdelenie Geologii, Geophiziki, i Geokhimii, Voprosy Mikropaleontologii, Moskva, 14, 3-16.

Rich, M. 1980. Carboniferous calcareous foraminifera from northeastern Alabama, south-central Tennessee, and northwestern Georgia. Cushman Foundation for Foraminiferal Research, Special Publication, Washington D.C., 18, 62 pp.

Rich, M. 1986. Foraminifera, Stratigraphy and Regional interpretation of the Bangor Limestone in northwestern Georgia. Journal of Foraminiferal Research, 16, 110134.

Ross, C.A. 1967. Late Paleozoic Fusulinacea from northern Yukon Territory. Journal of Paleontology, 41, 709-725.

Rozovskaya, S.E. 1961. On the systematics of the Endothyridae and the Ozawainellidae families [in Russian]. Akademiya Nauk SSSR, Paleontologicheskii Zhurnal, 3, 19-21.

Rozovskaya, S.E. 1963. Oldest representatives of the Fusulinidae and their ancestors [in Russian]. Akademiya Nauk SSSR, Trudy Institut Paleontologiy, 97, 3-128.

Rozovskaya, S.E. 1975. Composition, systematics, and phylogeny of the order Fusulinida [in Russian]. Akademiya Nauk SSSR, Trudy Institut Paleontologiy, 149, 267 pp.

Rumyantseva, Z.S. 1970. Stratigraphy and Foraminifera of the Namurian and Lower Bashkirian deposits of the Tchatkal Mountain System. In: Biostratigraphy of sedimentary formations of Uzbekistan [in Russian]. Ministerstvo Geologii Uzbekskoi SSR, Tashkentskii Geologo-Razvedochnii Trest, Tashkentgeologii, Kompleksnaya Geologos'emochnaya poiskovaya ekspediciya, Izdatel'stvo Nedra, 9, 138-184.

Ryazanov, G.F. 1958. Some new fusulinid species from Middle/Upper Carboniferous boundary beds in the northeastern part of the Great Donbass [in Russian]. Uchenye Zapiski Rostovskogo Gosudarstvennogo Universiteta, 53(9), 71-84.

Sada, K. 1975. Early and Middle Pennsylvanian Fusulinacea from Akiyoshi. Memoirs of the Faculty of Integrated Arts and Sciences, IV, Hiroshima University, 1, 29 pp.

Saurin, E. 1967. Endothyridae et Fusulinidae du Moscovien inférieur (Bachkirien) de la Grande Norway (Golfe du Nord Viêt-Nam). Archives Géologique Viêt-Nam, Service Géologique, Saigon, 10, 111-149.

Saurin, E. 1970. Foraminifères du Carbonifère-Moyen du Laos et du Nord Viêt-Nam. Archives Géologique ViêtNam, Service Géologique, Saigon, 13(1), 101-197.

Sebbar, A. 1997. Foraminifères benthiques carbonifères des bassins d'Abadla et de Béchar, Sahara septentrional, Algérie. Bulletin du Service Géologique de l'Algérie, 8 (2), 109-133.

Semichatova, S.V., Einor, O.L., Kireeva, G.D., Vassilyuk, N.P., Gubareva, V.S. and Potievskaya, P.D. 1979. The Bashkirian stage as a global stratigraphic unit. In: The Carboniferous of the U.S.S.R. (Coord. R.H. Wagner, A.C. Higgins, S.V. Meyen). Yorkshire Geological 
Society, 4, 99-116.

Sheng, J.C. 1958. Fusulinids from the Penchi series of the Taitzeho Valley, Liaoning [in Chinese and English]. Palaeontologica Sinica, Peking, Series B, 143(7), 55119.

Shlykova, T.I. 1951. Foraminifera of the Viséan and Namurian stages (Lower Carboniferous) of the western flank of the Moscow Basin [in Russian]. Vsesoyuznii Neftyanoi Nauchno-Issledovatel'skii GeologoRazvedochnii Instituta (VNIGRI), Trudy, Novaya Seriya, 56, 109-176.

Sinitsyna, Z.A. and Sinitsyn, I.I. 1987. Biostratigraphy of the Bashkirian stage in its type area [in Russian]. Akademiya Nauk SSSR, Bashkirskij Filial, Institut Geologii, Ufa, 71 pp.

Solovieva, M.N. 1984. The lower boundary of the Upper Carboniferous on the foraminifers in the Yugorsky peninsula. In: The Upper Carboniferous of the SSSR [in Russian]. (Coord. V.V. Menner and A.D. Grigoreva). Akademiya Nauk SSSR, Ministerstvo Geologii SSSR, Trudy, 13, 121-156.

Solovieva, M.N. 1991. In: Permian invertebrates of southern Mongolia (In: Joint Soviet-Mongolian palaeontological expedition [in Russian]. E.E. Pavlova, I.N. Manankov, I.P. Morozova, M.N. Solovieva, O.D. Suetenko and M.F. Bogoslovskaya). Moscow, Nauka, 40, 40-41.

Thompson, M.L. 1942. New genera of Pennsylvanian fusulinids. American Journal of Science, 240 403-420.

Thompson, M.L. 1944. Pennsylvanian Morrowan rocks and fusulinids of Kansas. Kansas State Geological Survey, 52, 409-431.

Thompson, M.L. 1945. Pennsylvanian rocks and fusulinids of east Utah and northwest Colorado correlated with Kansas section. Kansas State Geological Survey, 60(2), 17-84.
Thompson, M.L. 1951. New genera of fusulinid foraminifera. Cushman Foundation for Foraminiferal Research, Contributions, 2(4), 115-119.

Vachard, D. et Maslo, A. 1996. Précisions biostratigraphiques et micropaléontologiques sur le Bashkirien d'Ukraine (Carbonifère Moyen). Revue de Paléobiologie, 15, 357-383.

Vissarionova, A.I. 1948. Primitive fusulinids from the Lower Carboniferous of the European part of the USSR. In: Stratigraphy and foraminifera of the Lower Carboniferous of the Russian Platform and the Cis-Ural region [in Russian]. (Coord. D.M. RauzerChernousova). Akademiya Nauk SSSR, Institut Geologicheskikh Nauk, Trudy, Moskva, 62, 216-226.

Wagner, R.H., Higgins, A.C. and Meyen, S.V. (Eds.) 1979. The Carboniferous of the U.S.S.R. Yorkshire Geological Society, 4, $247 \mathrm{pp}$.

Wang, L. 1981. Some new species of fusulinids from the Carboniferous-Permian of Anhui, China [Chinese with a summary in English]. Acta Palaeontologica Sinica, 20 (2), 127-137.

Weyant, M. 1982. A proposal for a major boundary in the Carboniferous System based on conodont evidence from the Béchar Basin (Algeria). In: Biostratigraphic data for a Mid-Carboniferous boundary (Coord. W.H.C. Ramsbottom, W.B. Saunders, B. Owens). Meeting of IUGS Subcommission on Carboniferous Stratigraphy (Leeds, 1981), 19-21.

Zeller, D.E.N. 1953. Endothyroid foraminifera and ancestral fusulinids from the type Chesteran (Upper Mississippian). Journal of Paleontology, 27, 183-199.

Zhao, Z.X., Han, J.X., Wang Z.J., 1984. The Carboniferous strata and its fauna from southwestern margin of Tarim Basin in Xinjiang. Geological Publishing House, Beijing China, 187 pp.

\section{APPENDIX}

Lithology of Hassi Kerma Formation (from sampling locality SA 17 downward) and Tagnana-III Member. Locality

Thickness (m.)

SA 17 Two banks of well-layered grey limestone (abundant débris of recristallized algae)

Poorly exposed sequence; includes oolitic limestone and some friable sandstone

Dark grey limestone

Poorly exposed sequence; contains sandstone, quartzitic sandstone and thin beds of fossiliferous limestone

Yellow-greenish weathering, fossiliferous oolitic limestone 
Cross-bedded sandstone showing a limestone -breccia at its base

\section{Inferred upper boundary of Tagnana-III}

Dark grey limestone

SA 13 Poorly exposed sequence; includes shale occasionally with silicified mollusks, and thin beds of oolitic limestone 16

Grey limestone with Syringopora

Poorly exposed sequence including shale and thin layers of oolitic limestone

Yellow-brown weathering dolostone

Quartzitic sandstone alternating with grey and yellow-greenish oolitic limestone

SA 11 Massive limestone, possibly comparable with calcaire massif gris en gros blocs (Legrand-Blain, 1967, p. 304)

Friable or quartzitic sandstone

Fossiliferous (brachiopods) calcareous shale

\section{Unconformable contact?}

High limestone cliff (probably Tagnana-II Member) 